\title{
Backlash against International Courts in West, East and Southern Africa: Causes and Consequences
}

\author{
Karen J. Alter*, James T. Gathii** and \\ Laurence R. Helfer***
}

\begin{abstract}
This article discusses three credible attempts by African governments to restrict the jurisdiction of three similarly situated sub-regional courts in response to politically controversial rulings. In West Africa, when the Court of the Economic Community of West African States (ECOWAS) upheld allegations of torture by opposition journalists in Gambia, that country's political leaders sought to restrict the Court's power to review human rights complaints. The other member states ultimately defeated Gambia's proposal. In East Africa, Kenya failed in its efforts to eliminate the East African Court of Justice (EACJ) and to remove some of its judges after a decision challenging an election to a sub-regional legislature. However, the
\end{abstract}

* Professor of Political Science and Law at Northwestern University and Permanent Visiting Professor at iCourts: Centre of Excellence for International Courts, University of Copenhagen, Denmark. Email: kalter@northwestern.edu. Earlier versions of this article were presented at the American Political Science Association's 2014 Conference, the American Society of International Law's 2014 Research Forum, the European Society of International Law's 2015 Annual Meeting, Remin University Law School, Stanford University's International Relations Seminar and the University of California Los Angeles International Relations/International Law Workshop. Thanks to Shai Dothan, Solomon Ebobrah, Eric Stover, Mihreteab Tsige Taye and Erik Voeten for helpful comments on earlier drafts and to Kristina Alayan, Julienne Grant, Ethan Blevins, James Simpson, Abraham Smith, Sarah Tishler, Mihreteab Tsinge Taye, Alison Wallace and Chloe Bremer for excellent research assistance. We are also grateful for the financial support of iCourts: The Center of Excellence for International Courts at the University of Copenhagen; the Danish National Research Foundation, Grant no. DNRF105; the Equality, Development and Globalization Studies Center at the Buffett Institute, Northwestern University; the Center for International and Comparative Law, Duke University and Loyola University of Chicago Law School.

** Wing-Tat Lee Chair in International Law, Loyola University of Chicago, United States. Email: jgathii@luc. edu.

*** Harry R. Chadwick, Sr., Professor of Law, Duke University and Permanent Visiting Professor at iCourts: Centre of Excellence for International Courts, University of Copenhagen, Denmark. Email: helfer@law. duke.edu. 
member states agreed to restructure the EACJ in ways that have significantly affected the Court's subsequent trajectory. In Southern Africa, after the Southern African Development Community (SADC) Tribunal ruled in favour of white farmers in disputes over land seizures, Zimbabwe prevailed upon SADC member states to suspend the Tribunal and strip its power to review complaints from private litigants. Variations in the mobilization efforts of community secretariats, civil society groups and sub-regional parliaments explain why efforts to eliminate the three courts or narrow their jurisdiction were defeated in ECOWAS, scaled back in the EACJ and largely succeeded in the SADC.

\section{Introduction}

Many scholars, journalists and attorneys express concern about backlashes against international courts. Upon investigation, most supposed examples of backlash turn out to be little more than piqued criticisms, impassioned speeches or policy suggestions that are never seriously pursued. In fact, the vast majority of state-approved revisions of international court-founding treaties have expanded the courts' jurisdiction and access rules rather than overturning disfavoured decisions or sanctioning judges. This article provides new evidence that is at odds with this sanguine account. We explore credible backlash threats against three similarly-situated international courts in Africa over the last decade. In all three instances, an African government responded to a politically controversial ruling by a sub-regional court with a formal sanction proposal - to eliminate the court, narrow its jurisdiction and access provisions or augment the rules for disciplining its judges.

The outcomes of these proposals were strikingly different, however. In West Africa, states rejected the Gambia's effort to curb the Economic Community of West African States (ECOWAS) Court's broad access to private litigants in human rights cases. In East Africa, while Kenya failed to persuade neighbouring countries to eliminate the East African Court of Justice (EACJ) or oust its Kenyan judges, it restricted the Court in other ways, creating an appellate division staffed with more conservative judges, approving strict time limits for filing complaints and adding rules for removing judges. In Southern Africa, Zimbabwe prevailed upon the Southern African Development Community (SADC) member states to suspend the SADC Tribunal and its judges and later to strip the Court of the power to review complaints from private litigants.

This article provides the first ever comparative documentation and analysis of these three backlashes and their varied outcomes. We draw heavily on field research in West Africa in 2011, and in East and Southern Africa in 2013 and 2014, including over 50 interviews and two workshops with government officials, human rights lawyers, bar associations, international and national judges and the staff of the secretariats of the sub-regional communities. A review of the Courts' case law, non-governmental organizations (NGO) press releases and news media reports provides additional context for our analysis. 
Our findings provide new evidence to explore theoretical debates relating to international courts, including whether international judges are independent of states and the extent to which international adjudication is bounded by political constraints. Rationalist theories expect judges to anticipate and avoid negative political responses. The judges on all three recently created international courts could readily anticipate that their rulings would provoke a heated governmental reaction. Yet they issued their controversial rulings even when it was clear that governments stood ready to respond within court-curbing plans. What explains this audacious behaviour? Our answer emphasizes the judges' awareness that non-state actors in the sub-regions - officials with community secretariats and lawyers associations, in particular - were likely to back the courts and mobilize in support of their rulings. Variations in the extent and political influence of this mobilization and in the independence and political power of civil society groups, on the one hand, and regional secretariats and parliaments, on the other, helps explain the divergent outcomes in each sub-region.

The second part of this article describes the backlash attempts against the ECOWAS, the East African Community (EAC) and SADC courts. The third part distils the similarities and differences across the three cases, arguing that relative state power, variations in institutional design and the subject matter of each case triggering the backlash do not sufficiently explain the divergent outcomes. We show that consensus voting rules and political inertia make successful backlash efforts difficult to achieve, and, thus, extra-legal manoeuvring is key to changing the status quo. The fourth part analyses how backlash efforts are derailed. We focus on the extent to which community secretariats, civil society groups and sub-regional parliaments can delay or thwart extra-legal strategies, buying time and creating opportunities for court supporters to mobilize. The fifth part concludes by briefly discussing other implications of our findings for the study of international courts.

\section{Backlashes against Three Sub-Regional Courts in Africa}

This section explains the causes and consequences of the three international court backlashes. The three courts are alike in several respects. Each is associated with a sub-regional integration community in which the primary goal of economic liberalization is supplemented by a softer commitment to human rights and good governance - a commitment that has generated most of the cases decided by all three international courts. These communities include several common institutional features: the adoption of legally binding rules and collective decisions by consensus; a requirement to consult with civil society groups and, in principle at least, a commitment to put common state and societal interests above the preferences of any one government. Another similarity concerns the political and legal features of each community's member states. ECOWAS, the EAC and the SADC are each comprised of a mix of emerging or fragile democracies and authoritarian regimes. And all three include national legal systems with little tradition of judicial independence and at least some countries where the rule of law is fragile or illusory. Yet another commonality relates 
to the design features of each international court, in particular, the ability of individuals and NGOs to file suits directly with the courts against member states alleging violations of international law.

However, the three sub-regional courts are also hard cases for resisting a backlash. In comparison to Europe, the relatively small size of each community should facilitate coordination to sanction judges or restrict a court's jurisdiction and access rules. Moreover, many African nations have a tradition of strong executive branches, weak judiciaries, citizens who share a deep post-colonial distrust of external interference and, relatedly, a reluctance on the part of political leaders to openly challenge the actions of other African governments.

Since very little is known about these courts or the backlashes against them, our account is fairly detailed. We begin with a summary of each community's origins and institutions, identifying key similarities and differences across the three systems. We then describe the international court rulings that precipitated the backlash in each sub-region, including the government proposals to eliminate the courts or narrow their jurisdiction. We conclude by analysing the role of governments, community secretariats, civil society groups and the judges themselves in orchestrating or thwarting the backlash.

\section{A The ECOWAS Court of Justice: A Failed Backlash}

The 2009 backlash against the ECOWAS Court stemmed from suits against the Gambia that fell squarely within the court's human rights authority. A 2005 Supplementary Protocol gives the ECOWAS Court broad jurisdiction over human rights suits. ${ }^{1}$ Private litigants from all 15 West African nations have direct access to the Court without the need to exhaust domestic remedies, a requirement imposed by most global and regional human rights systems. Among the first human rights suits to reach the ECOWAS Court were two complaints filed in 2007 by an NGO, the Media Foundation for West Africa, on behalf of Gambian journalists who had been detained and allegedly tortured for publishing news articles critical of the government. ${ }^{2}$ The Gambia has long been ruled by one of the most repressive regimes in West Africa. Police and intelligence agents of President Yahya Jammeh regularly harass independent and opposition media and exercise tight control over the country's judges. ${ }^{3}$

1 Supplementary Protocol A/SP.1/01/05 Amending the Preamble and Articles 1, 2, 9, and 30 of Protocol A/P.1/7/91 Relating to the Community Court of Justice and Article 4 Paragraph 1 of the English Version of the Said Protocol (2005 Supplementary Protocol) (2005), available at http://www.courtecowas.org/ site2012/pdf_files/supplementary_protocol.pdf (last visited 16 March 2016), Arts 3, 4. For additional background on the origins of the Economic Community of West African States (ECOWAS) Court and the Protocol, see Alter, Helfer and McAllister, 'A New International Human Rights Court for West Africa: The ECOWAS Community Court of Justice', 108 American Journal of International Law (2013) 737.

2 ECOWAS Court, Manneh v. The Gambia, ECW/CCJ/JUD/03/08, 5 June 2008; ECOWAS Court, Saidykhan v. The Gambia, ECW/CCJ/RUL/05/09, 30 June 2009.

3 US Department of State, Country Reports on Human Rights Practices for 2013: The Gambia: Executive Summary (2013). 
Given this climate of repression, the two ECOWAS suits provoked a hostile reaction. As one West African human rights lawyer explained, Jammeh had already 'conquered his own judiciary,' and he 'refused to be bound by a court in Abuja' (the seat of the ECOWAS Court). ${ }^{4}$ The Gambia flatly ignored multiple requests to file documents or appear in court in the first suit by Chief Ebrima Manneh. The government's stonewalling strategy backfired. In June 2008, the ECOWAS judges issued a carefully reasoned and evidence-rich decision finding the Gambia responsible for torture and other human rights abuses and ordering the government to release Manneh from detention and pay him US $\$ 100,000 .^{5}$

The ECOWAS Court's judgment in the Manneh case sent shock waves across West Africa. As the same human rights lawyer noted, "with a $\$ 100,000$ fine, the embarrassment was huge'. ${ }^{6}$ The case and the repression of journalists that it exposed received widespread negative publicity. As one NGO press release explained, '[t]he Gambian media environment has long been hostile and dangerous, but the government's flagrant disregard for the ECOWAS legal proceedings represents a low point'. ${ }^{7}$ Foreign governments and international organizations were equally damning and demanded that the Gambia fully comply with the Court's judgment. ${ }^{8}$

The second suit, concerning the detention and torture of Musa Saidykhan, was harder to ignore - the journalist was alive, exhibited clear signs of torture and pursued the case from the safety of exile. ${ }^{9}$ The government responded to Saidykhan's suit with a broadside of legal and political arguments, including a claim that the suit was 'an affront to [Gambian] sovereignty'. ${ }^{10}$ The ECOWAS judges stood their ground. In June 2009, the Court published an interim ruling that considered and rejected each of the government's objections. ${ }^{11}$

Having failed to defeat Saidykhan's suit with procedural objections, President Jammeh adopted a different strategy, working within ECOWAS to challenge the Court's human rights jurisdiction. In September 2009, the Gambia submitted to the ECOWAS Commission - the sub-regional Secretariat - an official request to revise the 2005 Supplementary Protocol. ${ }^{12}$ The request was accompanied by the text of a draft Supplementary Act consisting of six amendments to the ECOWAS Court's powers:

\footnotetext{
Interview with Human Rights Advocate C by telephone (10 February 2011).

Manneh, supra note 2, paras 4, 28, 44.

Interview with Human Rights Advocate C by telephone (10 February 2011).

International Press Institute, 'IPI Calls on the Gambian Government to Cooperate with ECOWAS

Legal Proceedings', Senegambia News (13 March 2008), available at http://allafrica.com/stories/200803170690.html (last visited 17 March 2016) (copy also on file with authors).

8 Rhodes, 'Six Senators Call for Ebrima Manneh's Immediate Release', Committee to Protect Journalists (23 April 2009), available at https://cpj.org/blog/2009/04/six-senators-call-for-ebrima-mannehsimmediate-rel.php (last visited 17 March 2016). Linda Akrasi Kotey, 'Ghana: Akoto Ampaw, Two Others in Gambia', Ghanaian Chronicle (17 July 2009), available at http://allafrica.com/stories/200907171086. html (last visited 16 March 2016).

9 'ECOWAS Torture Case against the Gambia Nears an End', Afrol News (22 September 2010), available at www.afrol.com/articles/36623 (last visited 16 March 2016).

10 Saidykhan, supra note 2, para 11.

11 Ibid., para 37.

122005 Supplementary Protocol, supra note 1.
} 
(a) that with respect to human rights cases, the Court should only have jurisdiction in cases arising from international instruments ratified by the respondent country;

(b) also in human rights cases, the ECOWAS Court's jurisdiction should be made subject to the exhaustion of domestic remedies;

(c) cases should only be admissible if instituted not later than 12 months after the exhaustion of local remedies;

(d) cases should not be anonymous;

(e) the Court should not hear cases that are before other international mechanisms of settlement; ${ }^{13}$ and

(f) to create an appeals procedure. ${ }^{14}$

On their face, these proposals appear relatively modest and uncontroversial. For the Media Foundation for West Africa and other human rights groups in the region, however, the true motivation for the proposals and their harmful consequences were immediately apparent.

According to a joint press release issued by 11 NGOs, the Gambia proposed the amendments to weaken the ECOWAS Court's 'capacity to deal effectively with tyrannical governments trampling on citizens' rights' and to 'depriv[e] citizens of free access' to an 'independent judicial instrument that is not usually available in many countries' in a region 'where the judiciary is an arm of the executive'. The NGOs also characterized the attempt to limit the Court's jurisdiction as a ploy to prevent the Court from hearing Saidykhan's suit against the Gambia - one of 'the rare African countries which have not ratified the United Nations Convention against Torture'. ${ }^{15}$ The press release urged the ECOWAS Commission to invite civil society groups to a proposed experts' meeting that it had convened to review the Gambia's proposals or to postpone the meeting 'until there are broad consultations with representatives of civil society organizations'. ${ }^{16}$

In fact, officials in the ECOWAS Commission's Legal Affairs Directorate had already reached out to key lawyers and rights groups. ${ }^{17}$ To turn up the heat in advance of the meeting, two leading human rights organizations - the Registered Trustees of the Socio-Economic Rights and Accountability Project and the Centre for Defence of Human Rights and Democracy in Africa, represented by the influential head of the

13 'West Africa: Country Submits Proposals to Amend ECOWAS Protocol', FOROYAA Newspaper (Serrekunda, 25 September 2009), available at http://allafrica.com/stories/200909250810.html (last visited 16 March 2016); see also N. Adu Ampofo, 'Gambian Authorities Seek to Limit Reach of Regional Human Rights Court', Global Insight (28 September 2009).

14 A. Jallow, 'Rights Groups Sue Gambia over Access to ECOWAS Court', 30 September 2009, available at http://listserv.icors.org/scripts/wa-ICORS.exe?A2=ind0909E \&L=gambia-l\&F=\&S=\&P=11181 (last visited 16 March 2016).

15 International Freedom of Expression Exchange, 'Four IFEX Members, Civil Society Groups Fear Gambia Proposal Will Prevent ECOWAS Court from Ruling in Saidykhan Case', 28 September 2009, available at www.ifex.org/west_africa/2009/09/28/ecowas_court_jurisdiction/ (last visited 16 March 2016).

16 Ibid.

17 Interviews with Human Rights Advocates B (3 February 2011) and C by telephone (10 February 2011); Interview with ECOWAS Legal Affairs Directorate A in Abuja, Nigeria (7 March 2011). 
West African Bar Association, Femi Falana, filed an ex parte motion with the ECOWAS Court seeking an emergency order 'to stop the Government of Gambia and the ECOWAS Commission from amending the laws concerning the jurisdiction and access to' the Court. ${ }^{18}$ The suit, publicized in the news media, challenged the legality of the Gambian proposals on multiple grounds. It also tied the proposals to the Gambia's refusal to comply with the Manneh judgment. ${ }^{19}$

Two days later, legal experts from across West Africa gathered in the Nigerian capital to consider the proposals. Although accounts of the meeting differ on some details, all sources agree that an ECOWAS Committee of Legal Experts decisively recommended against narrowing the Court's human rights powers. ${ }^{20}$ One week later, the Council of Justice Ministers endorsed the legal experts' recommendation. Their decision effectively shelved the proposals. ${ }^{21}$ The Gambia could have sought a further review before the Council of Justice Ministers, but the government at this point abandoned its campaign to sanction the Court.

The Gambian backlash provided a clear opportunity for West African governments to reconsider the ECOWAS Court's expansive human rights jurisdiction and access rules. Their decision to decisively reject the Gambian challenge is striking. One explanation was the widely shared perception of the Gambia as a bad actor with limited political clout in ECOWAS. However, the defeat would not have occurred without the extensive mobilization efforts of human rights NGOs and attorneys. By issuing press releases, filing an emergency suit and demanding access to a key meeting, these actors ensured that the Gambia's campaign was well publicized, that consultation procedures were followed and that their voices would be heard when experts convened to discuss the proposals. ${ }^{22}$

Equally essential was the overt and tacit support of individuals within the ECOWAS Commission. The Commission had recently blessed the member states' decision to provisionally delegate capacious human rights authority to the then-inactive ECOWAS Court. The judges had just begun to exercise this authority, and one of their judgments - against Niger for condoning modern forms of slavery - received widespread recognition and praise, including in the foreign media. ${ }^{23}$ In addition, West African

18 Jallow, supra note 14 . The complaint was apparently withdrawn after the defeat of the Gambia's proposals.

19 I. Anaba, 'SERAP, CHRDA Challenge Plans to Amend ECOWAS' Court Powers', Vanguard (Nigeria, 26 June 2008).

20 Interview with Human Rights Advocate C by telephone (10 February 2011); Interview with Human Rights Advocate A by telephone (11 January 2011); M. Nyang, 'Amendment [sic] to ECOWAS Court Mandate: Gambia Isolated By State Parties', 30 September 2009, available at http://listserv.icors.org/ scripts/wa-ICORS.exe?A2=ind0910A\&L=gambia- $\& \mathrm{~F}=\& S=\& \mathrm{P}=76$ (last visited 16 March 2016).

21 Sources disagree as to whether the justice ministers rejected the Gambian proposal unanimously, defeated it by a 9-6 vote or whether the government withdrew the proposal. See Media Foundation for West Africa, Press Statement: Justice Ministers Endorse Experts' Decision, 14 October 2009, available at www.ifex.org/west_africa/2009/10/14/gambian_proposal_defeated/ (last visited 16 March 2016); Interview with Human Rights Advocate A by telephone (11 January 2011); Interview with Human Rights Advocate C by telephone (10 February 2011).

22 Interview with ECOWAS Legal Affairs Directorate A in Abuja, Nigeria (7 March 2011).

23 ECOWAS Court, Hadijatou Mani Koraou v. Niger, Judgment, ECW/CCJ/APP/08/07, 27 October 2008; see also L. Polgreen, 'Court Rules Niger Failed by Allowing Girl's Slavery', New York Times (28 October 2008), at A6. 
governments had doubled down on their support of the Court in 2006 by creating a Judicial Council to screen applications for open judgeships and recommend a slate of the best qualified candidates to the member states. ${ }^{24}$ To impose additional hurdles to private litigants suits just as the Court was beginning to hear cases would have undercut these political and institutional investments in the community's fledgling judicial body - an outcome that Commission officials disfavoured. ${ }^{25}$

Since the rejection of its proposals, the Gambia has continued to flout the ECOWAS Court's 2007 decision in the Manneh case and its 2010 judgment in favour of the second journalist, Musa Saidykhan. ${ }^{26}$ However, the defeat of the government's campaign had the opposite of its intended goal. The Court has continued to develop its human rights jurisprudence, albeit in a manner suggesting its awareness of the political limits of its authority and the serious obstacles to securing compliance with its judgments. The judges have condemned clear human rights abuses while rejecting litigant pleas to construe its jurisdiction expansively and using public speeches to urge governments to comply with its judgments. ${ }^{27}$

The Court has pursued these actions notwithstanding a multi-year delay in judicial appointments, during which time the existing judges remained in office and continued to hear cases. ${ }^{28}$ With the swearing in of a new slate of seven judges recommended by the Judicial Council in 2014, ${ }^{29}$ the ECOWAS Court's formal human rights authority now rests on a more solid legal and political foundation.

\section{B The EACJ: A Backlash Redirected}

The current EAC is a revival of an earlier EAC that operated from 1967 to 1977 and consolidated colonial era regional institutions dating back to 1917. The re-establishment of the EAC in 1999 reflected a renewed commitment to sub-regional integration and cooperation that involves not only states but also the private sector and peoples of East Africa. The EAC's judicial arm has a similar historical legacy. The EACJ replaced

24 Decision A/Dec.2/06/06 Establishing the Judicial Council of the Community, adopted 14 June 2006. The Council comprises the presidents and chief justices from member states not then represented on the seven-member ECOWAS Court.

25 Interview with a legal adviser at the ECOWAS Legal Affairs Directorate in Abuja, Nigeria (7 March 2011).

26 In 2010, the ECOWAS Court issued a judgment holding the Gambia responsible for illegally detaining and torturing Saidykhan and awarding him damages of US \$200,000. ECOWAS Court, Saidykhan v. The Gambia, Judgment, ECW/CCJ/APP/11/07, 16 December 2010, para. 47. In 2011, the Gambia denied responsibility for Manneh's death and asked the court to set aside both judgments on the ground that the judges failed to properly assess the evidence. In 2012, the Court rejected the Gambia's arguments and reaffirmed the judgments. The USA, the United Kingdom and non-governmental organizations (NGOs) continue to push for compliance in country reports and before United Nations human rights bodies.

27 See Alter, Helfer and McAllister, supra note 1, at 766-768.

28 Protocol A/P.I/7/91: On the Community Court of Justice Protocol A/P.l/7/91 on the Community Court of Justice (1991), available at http://www.courtecowas.org/site2012/pdf_files/protocol.pdf (last visited 16 March 2016),Art. 4(3) provides: 'At the expiration of the term of a member of the Court, the said member shall remain in office until the appointment and assumption of office of his successor.'

29 ECOWAS, Judicial Council Endorses Recruitment of 7 Judges for ECOWAS Court of Justice, Press Release No. 051/2014, 21 March 2014. 
the East African Court of Appeal, which closed down in 1977 with the collapse of the earlier EAC. While the EACJ, launched in 2001, is sometimes confused with its precursor, it is an international court charged with interpreting and applying EAC treaties and other community legal texts. ${ }^{30}$

The most controversial aspect of the EACJ's jurisdiction concerns human rights. ${ }^{31}$ Unlike the ECOWAS Court, which has an express mandate to hear human rights suits, and the SADC Tribunal, which interprets a sub-regional treaty that arguably includes human rights commitments, the EAC Treaty explicitly states that the EACJ shall have a human rights jurisdiction 'as will be determined by the [EAC] Council at a suitable subsequent date' once member states 'conclude a protocol to operationalise the extended jurisdiction'. 32

EAC member states have not adopted such a protocol, yet human rights cases comprise most of the EACJ's docket. ${ }^{33}$ This paradox is the result of sustained advocacy by human rights lawyers in East Africa, who have urged the Court to adjudicate violations of the rule of law, social justice and human rights in the EAC Treaty's objectives and fundamental principles clauses, even in the absence of the protocol's adoption. ${ }^{34}$ EAC member states have repeatedly contested the EACJ's jurisdiction to entertain these suits. Yet the Court, while acknowledging that it is not a human rights tribunal as such, has repeatedly asserted its power to interpret EAC legal instruments relating to human rights.

The case that provoked a backlash did not, however, involve human rights. In its first ruling under its contentious jurisdiction, ${ }^{35}$ the EACJ rejected the slate of candidates chosen by Kenya to sit in the East African Legislative Assembly (EALA). The legal issue concerned Article 50 of the EAC Treaty, which requires an election for seats in the EALA. ${ }^{36}$ Instead, the Kenyan government divided the seats among the country's political parties in proportion to their strength in the national Parliament - a move that the opposition party viewed as an attempt to control the domestic legislative agenda and renege on promises to share power. ${ }^{37}$

Treaty for the Establishment of the East African Community (EAC Treaty) 1999, 2144 UNTS 255, Art. 27(1).

31 See Gathii, 'Mission Creep or a Search for Relevance: The East African Court of Justice's Human Rights Strategy', 24 Duke Journal of Comparative and International Law (2014) 249.

32 EAC Treaty, supra note 30, Art. 27(2).

33 Decisions of the East African Court of Justice (EACJ), available at http://eacj.org/?page_Ibid=2414 (last visited 16 March 2016). Many complainants to the EACJ seek preliminary injunctive relief; thus, a majority of the court's rulings are interim decisions. The EACJ website indicates that the Court had issued 53 final judgments as of November 2015. The total tally of all final judgments, interim decisions, interlocutory appeals and tax and cost rulings issued as of the same date is 113 .

34 EAC Treaty, supra note 30, Art. 6(d) (fundamental principles), Art. 7(2) (operational principles).

35 EACJ, Anyang Nyong'o v. Attorney General of Kenya, Reference No. 1 of 2006, 27 November 2006, available at http://eacj.huriweb.org/wp-content/uploads/2006/11/EACJ_rulling_on_injunction_ref_ No1_2006.pdf (last visited 16 March 2016).

36 EAC Treaty, supra note 30, Art. 50 'stipulates that the elected members shall, as much as feasible, be representative of specified groups, and sets out the qualifications for election'.

37 Nyong'o, supra note 35, at 2-5. 
Opposition politicians turned to the EACJ hoping to inflict an embarrassing loss on the governing party in the lead up to national elections. The key event triggering the backlash against the Court was an interim ruling in Anyang Nyong'o v. Attorney General of Kenya that barred EAC officials from recognizing Kenya's slate of EALA nominees until the Court had decided the case on its merits. The ruling incensed the Kenyan government, triggering a campaign to kill the sub-regional court and exert greater control over its judges. We highlight those aspects of the dispute that are relevant to the Kenyan backlash and the responses by other EAC member states, civil society groups, the EAC Secretariat and the EALA. ${ }^{38}$

The EACJ's interim ruling is noteworthy for its unvarnished conclusion that Kenya had breached the EAC Treaty by holding a 'fictitious election in lieu of a real election' and for the issuance of an interim injunction that delayed the EALA's second session by more than six months. ${ }^{39}$ Two aspects of the ruling especially vexed the government. First, Kenya viewed the decision as unwelcome external interference in a sensitive domestic political dispute and, even worse, as taking the opposition's side. Kenya's president went so far as to label the EACJ's ruling as undermining the country's sovereignty. ${ }^{40}$ Second, Kenya objected to the Court's conclusion that its interpretation of the EAC Treaty binds national courts and that the standing and exhaustion of domestic remedies doctrines did not bar the Court from hearing suits from private litigants. ${ }^{41}$

Kenya's reaction to the Nyong'o ruling was swift and furious. Officials pursued several lines of attack more or less simultaneously. When one avenue was thwarted, the government pushed ahead with other strategies, ultimately succeeding in rushing through amendments to the EAC Treaty that curbed the EACJ's authority. Kenya's first move, led by Attorney General Amos Wako just days after the Court's interim injunction, was a behind-the-scenes effort to kill the fledgling court. ${ }^{42}$ The proposal was not sympathetically received by Uganda and Tanzania, ${ }^{43}$ which supported the East African integration project and resisted regionalizing Kenya's domestic political squabbles. ${ }^{44}$ Tanzanian officials viewed the proposal as 'too extreme', ${ }^{45}$ while President Museveni of Uganda - who hoped to become the EAC's president should the EAC become a

38 A blow-by-blow account of the lengthy and complex Nyong'o litigation is beyond the scope of this article. For a comprehensive analysis, see Gathii, supra note 31, at 265-271.

39 Nyong'o, supra note 35, at 43; Interview with Judge C of the EACJ First Instance Division, Nairobi, Kenya (2 August 2013) (asserting that the EACJ was aware that the Nyong'o ruling would delay the East African Legislative Assembly's [EALA] opening).

40 Speech delivered by Kenyan President Kibaki, 8th EAC Summit, Arusha Tanzania, 30 November 2006, available at www.jaluo.com/wangwach/1206/Leo_Odera_Omolo120106a.html (last visited 16 March 2016) (noting that the 'ruling of the Court poses serious challenges to the East African Community' and that the 'Council of Ministers is well seized of these challenges and their grave implications').

41 Nyong'o, supra note 35, at 20.

42 Individuals with first-hand knowledge described the government's plans in off-the-record interviews.

43 Tanzania and Uganda were the only other member states of the East African Community (EAC) at the time. Rwanda and Burundi did not join the EAC until several years later.

44 G. Warigi, 'Our Free Wheeling Politics May Frustrate Regional Unity', Daily Nation (3 December 2006) available at http://allafrica.com/stories/200612040362.html (last visited 16 March 2016).

45 Interview with Human Rights Advocate L, Arusha, Tanzania (30 July 2013). 
political federation - shared with Tanzania an aversion to actions that could contribute to the collapse of the EAC. Blocked in its efforts to kill the Court, Kenya turned to a strategy that it could implement unilaterally - threatening to oust the EACJ's two Kenyan judges, one of whom was the Court's president. By removing the judges from the Nyong'o case, the government hoped to avoid an adverse ruling on the merits that would solidify the opposition's influence in the EALA.

During a status conference at the Court's seat in Arusha, Tanzania, a high-level legal team led by Kenya's solicitor general visited the EACJ president's chambers. The attorneys urged the president and his Kenyan colleague to recuse themselves from the Nyong'o case. If they did not, the solicitor general threatened to file a formal recusal motion asserting that the two jurists had engaged in 'corruption, unethical practice, and absence of integrity' in the performance of their judicial offices in Kenya. ${ }^{46}$ (Many EACJ judges continue to serve as national judges while serving on the sub-regional court, which is not a full-time judicial body.)

Refusing to accede to pressure tactics that the EACJ later described as 'akin to intimidation' ${ }^{47}$ and an 'ambush', ${ }^{48}$ the Kenyan jurists sought the advice of their colleagues, who unanimously backed them. At the public hearing on the recusal motion, the government made good on its threat to 'wash the dirty laundry' of the Kenyan judges. ${ }^{49}$ It argued that because the judges had been suspended from their duties on the Kenyan courts due to allegations of corruption, they could not render a fair judgment in the Nyong'o case. ${ }^{50}$ In the end, it was the government that was embarrassed. Kenya withdrew its complaint against one of the judges who had voluntarily resigned from his national judicial post after the government commended him for his service and wished him a 'prosperous time in the EACJ' ${ }^{51}$ Caught in its own inconsistency, the government apologized. ${ }^{52}$ As for the second judge, the EACJ found no basis to question his impartiality. A Kenyan court later found that the corruption investigation violated that judge's 'natural justice rights' and ordered his reinstatement. ${ }^{53}$

Undaunted by its inability to oust the Kenyan judges, the government pursued a third approach - amending the EAC Treaty. Kenya's treaty revision proposal had

46 EACJ, Attorney Gen. of Kenya v. Nyong'o, Application No. 5 of 2007, 6 February 2007, at 19; see also 'Kibaki Rails at EAC Court as Rwanda, Burundi Join Up', The East African (4 December 2006), available at www.theeastafrican.co.ke/news/-/2558/252342/-/t6awg5z/-/index.html (last visited 16 March 2016).

47 Nyong'o, supra note 46 , at 11.

48 Ibid., at 8-9; Interview with EACJ Appellate Judges A and B, Arusha, Tanzania (30 July 2013).

49 Interview with EACJ Appellate Judge A and President, Arusha, Tanzania (30 July 2013).

50 Nyong'o, supra note 46 , at 8.

51 Ibid., at 11, 14.

52 Ibid., at 12.

53 Republic v. Chief Justice of Kenya and Others Ex Parte Moijo Ole Keiwua (2010) eKLR. On the reinstatement, see P. Kameri Mbote and M. Aketch, Kenya: Justice Sector and the Rule of Law: A Review by AfriMAP and the Open Society Initiative for Eastern Africa (March 2011), at 111; M. Mati, 'Kenya is Guilty of Judicial Interference', The East African (26 February 2007), available at www.theeastafrican.co.ke/ opOrEd/-/434748/253402/-/rbk891z/-/index.html (last visited 16 March 2016). 
several objectives: to pressure the judges to avoid further adverse rulings in the Nyong'o case, to restrict the Court's ability to hear cases from private litigants, to establish an appellate chamber staffed by pro-government jurists and to create a procedure to remove judges for misconduct. ${ }^{54}$ The East African Law Society (EALS) denounced these proposals as a brazen and illegal ploy 'to threaten and cow down the Court' 55 and intimidate its judges. ${ }^{56}$

The amendments were proposed, drafted and adopted with exceptional haste, circumventing the EAC's institutional processes that opponents might have used to block or weaken the proposals. On 28 November 2006 - one day after the Nyong'o injunction - the EAC Council of Ministers called for a study of the Court's jurisdiction. Two days later, the three EAC presidents endorsed the Council's recommendations to reconstitute the EACJ as a two-level court with First Instance and Appellate Divisions, to expand the procedures for removing judges from office and to convene a special summit to adopt these changes as amendments to the EAC Treaty. ${ }^{57}$

On 7 December 2006, Kenyan Attorney General Wako chaired a meeting of EAC attorneys general to finalize draft amendments to the EAC Treaty that Wako himself had prepared. ${ }^{58}$ The very next day, the Council of Ministers convened an extraordinary meeting to approve the draft amendments. ${ }^{59}$ Uganda adopted the amendments on 11 December, Tanzania the next day and Kenya the day after. The summit endorsed the amendments on 14 December 2006 on the sidelines of a non-EAC meeting, ${ }^{60}$ and they entered into force in May 2007. ${ }^{61}$

The amendments substantially changed the EACJ's structure, jurisdiction and access rules. They split the Court into two divisions; provided rules for appeals to the Appellate Division; added new grounds for removing or suspending EACJ judges due to allegations of 'misconduct' in their home countries; clarified that the Court had no power to review cases for which 'jurisdiction [is] conferred by the Treaty on organs of Partner States' and added a two-month time limit for private litigants to file complaints challenging national actions or decisions that are contrary to the Treaty. ${ }^{62}$

54 Onoria, 'Botched-Up Elections, Treaty Amendments and Judicial Independence in the East African Community', 54 Journal of African Law (2010) 74, at 84.

55 EACJ, East African Law Society and 4 others v. Attorney General of Kenya and 3 others, Reference No. 3 of 2007, 30 August 2008; see also East African Law Society (EALS), No Integration without the Rule of Law, Press Release, 4 December 2006, at 2 (describing attempts 'to intimidate and bully the Court').

56 East African Law Society, supra note 55. See also 'Wagging Tongues over EALA Ruling Is Contempt of Court', Arusha Times (10-15 December 2006), available at http://allafrica.com/stories/200612110956. html (last visited 16 March 2016).

57 Communique of the Summit of the EAC Summit, 30 November 2006.

58 See Report of the Extraordinary Meeting of the Attorneys General on the Proposed Amendment of the Treaty for the Establishment of the East African Community, Reference EAC/AG/EX/2006, 7 December 2006, para. 2.0.

59 Report of the Extraordinary Meeting of the Council of EAC Ministers, 7-8 December 2006.

60 'East Africa: Irate Kibaki Clips the Wings of EACJ Judges', The East African (19 December 2006), available at http://allafrica.com/stories/200612190758.html (last visited 16 March 2016).

61 Onoria, supra note 54 , at 82, n. 49.

62 EAC Treaty (revised), supra note 30, Arts. 26(1), 26(2), 27(1), 30(2). 
The adoption of the amendments triggered a vociferous reaction from civil society groups, opposition politicians and the plaintiffs in the Nyong'o case, all of whom focused on the member states' circumvention of sub-regional and national rules and procedures. The EALS protested the exclusion of NGOs from the EAC-level amendment process. ${ }^{63}$ Kenyan legislators protested the adoption of the amendments by executive decree. ${ }^{64}$ The Nyong'o plaintiffs unsuccessfully challenged the amendments in a domestic suit before the High Court of Kenya. ${ }^{65}$ And academic commentators characterized the amendments as an attempt to weaken the EACJ. ${ }^{66}$

These contestations soon reached the EACJ when the EALS challenged the amendment's adoption. ${ }^{67}$ In an August 2008 decision, the Court agreed with the Law Society that the amendments were procedurally defective because the member states had not allowed the private sector and civil society to participate in their drafting. ${ }^{68}$ The EACJ also categorically rejected as a ‘veiled intimidation' Kenya's allegation that 'the hurried process [of adoption] was necessitated by the loss of public confidence in the court'. ${ }^{69}$ Yet the Court refrained from invalidating the amendments because the 'infringement was not a conscious one', the violation was 'not likely to recur' and 'not all the resultant amendments are incompatible with Treaty objectives'.$^{70}$ The decision can thus be viewed as a rhetorical judicial pushback but a substantive acquiescence to a political fait accompli.

Kenya's efforts to overturn the EACJ's edicts in the Nyong'o case were less successful, however. In March 2007, the Court confirmed its interim injunction against swearing in the Kenyan EALA members and ordered Kenya to conduct elections consistent with the EAC Treaty. ${ }^{71}$ The government sought to evade the judgment by lobbying Uganda and Tanzania, but the two states stood behind the EACJ. President Museveni of Uganda even sent emissaries to the Kenyan leaders, urging them to put their political house in order to avoid impeding the EAC integration agenda. ${ }^{72}$ Lacking the support of the other governments, Kenya finally capitulated. In May 2007, the Kenyan

63 See People's Daily Online, 16 December 2006, available at http://english.people.com.cn/200612/16/ print20061216_333151.html (last visited 16 March 2016).

64 Kenya Parliamentary Debates, National Assembly (Hansard), 16 May 2007, at 1339-1429, available at http://info.mzalendo.com/hansard/sitting/national_assembly/2007-05-16-09-00-00 (last visited 16 March 2016).

65 Nairobi High Court, Anyang Nyong'o and 10 Others v. AG, Civil Case No. 49, 2006, available at http:// kenyalaw.org/caselaw/cases/view/37525 (last visited 16 March 2016).

66 Onoria, supra note 54, at 83-94; A. Pieter van der Mei, The East African Community: The Bumpy Road to Supranationalism, Maastricht Faculty of Law Working Paper 2009-7 (2009), at 12.

67 EALS, supra note 55.

68 Ibid., at 13-14.

69 Nyong'o, supra note 46 , at 11

70 EALS, supra note 55, at 43-44.

71 Nyong'o, supra note 35 at 36.

72 N. Nyamboga, 'East Africa: Partner States Decline to Support Kenya's Plea', East African Standard (Nairobi, 9 May 2007), available at http://allafrica.com/stories/200705081068.html (last visited 16 March 2016). 
Parliament revised the rules for EALA membership and held fresh elections conforming to the Court's interpretation of the EAC Treaty. ${ }^{73}$

Although the EACJ survived Kenya's backlash campaign, the amendments to the EAC Treaty have altered its subsequent evolution. The two-month time limit for filing cases has presented challenges for lawyers, and the Appellate Division has reversed some of the First Instance Division's more expansive rulings. Yet both the chambers have adjudicated a broad range of legal issues covered by the EAC Treaty - in particular, suits alleging human rights violations. The EACJ's review of human rights suits is by far the most important post-Nyong'o development. In Katabazi v. Secretary General of the EAC, the EACJ held that it would not 'abdicate' jurisdiction over human rights complaints framed as breaches of the EAC Treaty's fundamental principles. ${ }^{74}$ This was a strikingly bold conclusion given the Treaty's explicit statement that the member states would confer such jurisdiction via a yet-to-be-adopted protocol. ${ }^{75}$

A series of human rights decisions have followed Katabazi, many of which have been filed by, or have the support of, the EALS. Both chambers of the EACJ have endorsed Katazabi's core holding, but the First Instance Division has been more permissive to private litigants, applying a continuing violations doctrine to circumvent the amendment's very short two-month window for challenging national policies and decisions that are contrary to the EAC Treaty. ${ }^{76}$ In contrast, the Appellate Division has strictly construed this provision, enabling governments to defeat several suits raising credible allegations of human rights violations. ${ }^{77}$

\section{The SADC Tribunal: A Successful Backlash}

Unlike its sub-regional cousins, whose integration projects have roots in the immediate post-independence period, the SADC is a more recent institution. When governments launched the SADC in the early 1990s, they solicited financial support from European governments. To make such assistance more enticing, the sub-region's political leaders decided to 'visibly emulate' the supranational 'EC-style common market model' without, however, giving much thought to its 'advantages and disadvantages' ${ }^{78}$ Thus, the emulation was in tension with the member states' desire to 'retain[] a more sovereignty-preserving institution "in practice". 79

73 East African Community (Election of Members of Assembly) Rules, 2007, adopted by the Parliament of Kenya, 23 May 2007. Elections under these rules were held on 29 May 2007. Election of Members of the EALA, Kenya Gazetter Notice No. 4873, vol. 109, No. 37, 31 May 2007.

74 EACJ, Katabazi v. Sec'y Gen. of the E. African Cmty, Reference No. 1 of 2007, 1 November 2007, at 1-2.

75 EAC Treaty, supra note 30, Art. 27(2).

76 E.g., Independent Medical Unit v. Attorney General of Kenya, Reference No. 3 of 2010 (1st Inst. Div.), 29 June 2011.

77 EACJ, Omar Awadh and 6 Others v. Attorney General of Uganda, Appeal No. 2 of 2012 (App. Div.), 15 April 2013, at 15.

78 Lenz, 'Spurred Emulation: The EU and Regional Integration in Mercosur and SADC', 35(1) West European Politics (2011) 155, 163.

79 Ibid., at 166; see also Nathan, 'The Disbanding of the SADC Tribunal: A Cautionary Tale', 35 Human Rights Quarterly (2013) 870, 876-877. 
The 1991 SADC Treaty envisioned that a tribunal would be created by a separate protocol ${ }^{80}$ In the late 1990s, after the SADC's membership expanded to include five more countries, including South Africa, ${ }^{81}$ the member states considered whether to adopt the protocol. Several governments voiced a preference for arbitration and mediation, but European donors expressed doubt that the SADC could advance subregional integration without a more 'effective and credible' dispute settlement mechanism. ${ }^{82}$ Partly in response to this external pressure, the SADC Protocol's drafters - who included a British judge funded by the European Community - created a tribunal modelled on the European Court of Justice, with direct access for private litigants (after exhausting domestic remedies) and a preliminary ruling mechanism. ${ }^{83}$

The new Tribunal's fate soon became inextricably linked to its first major case, filed in 2007 by Michael Campbell, a white landowner from Zimbabwe. ${ }^{84}$ The case was highly controversial, Campbell was a tenacious litigant, his attorneys were creative and aggressive and the suit challenged the signature land redistribution program of Zimbabwe's President Robert Mugabe - a former rebel leader lionized across the region for overthrowing white minority rule, but who is also one of Africa's most autocratic political leaders.

In post-independence Zimbabwe, the best land remained in the hands of a small number of white farmers. The government initially followed a 'willing seller, willing buyer' approach to land reform, but later began to forcibly expropriate white-owned landholdings. ${ }^{85}$ In 2006, the government notified Campbell that it intended to seize his farm. Campbell challenged the decision before the Zimbabwean Supreme Court. ${ }^{86}$ He also filed an application with the SADC Tribunal, alleging discrimination on the basis of race, lack of due process in the deprivation of property and denial of access to the courts. ${ }^{87}$

Over the next several years, the SADC judges issued a series of audacious interim rulings, judgments and contempt orders in favour of Campbell and 77 other white

80 Treaty of the Southern African Development Community (SADC Treaty), available at http://www.sadc. int/files/8613/5292/8378/Declaration_Treaty_of_SADC.pdf (last visited 16 March 2016), Art. 16.

81 The original Southern African Development Community (SADC) member states were Angola, Botswana, Lesotho, Malawi, Mozambique, Namibia, Swaziland, Tanzania, Zambia and Zimbabwe. Mauritius, the Democratic Republic of the Congo, the Seychelles, South Africa and Madagascar joined the SADC between 1995 and 2006.

82 Lenz, supra note 78 , at 166.

83 Protocol on Tribunal and Rules of the South African Development Community (SADC Protocol), available at www.sadc.int/files/1413/5292/8369/Protocol_on_the_Tribunal_and_Rules_thereof2000.pdf (last visited 16 March 2016), Arts 15, 16.

84 SADC Tribunal, Campbell and Others v. Zimbabwe (Merits), Case No. SADC (T) 2/2007, 28 November 2008, at 4 (complaint filed 11 October 2007).

85 Moyo, 'Land Reform and Redistribution in Zimbabwe since 1980', in S. Moyo and W. Chambati (eds), Land and Agrarian Reform in Zimbabwe: Beyond White-Settler Capitalism (2013) 29.

86 Minister of National Security Responsible for Land, Land Reform and Resettlement, Constitutional Application No. 124/06, Judgment No. SC 49/07, 22 January 2008, at 2, available at www.zimlii.org/zw/judgment/ supreme-court/2008/1 (last visited 16 March 2016).

87 See Campbell, supra note 84 , at 16-17. 
farmers whose suits were joined to his case. ${ }^{88}$ In November 2007, the Tribunal issued a preliminary injunction preventing Zimbabwe from evicting Campbell or interfering with his use of the land. ${ }^{89}$ Mugabe's supporters responded to the ruling by kidnapping and roughing up Campbell and his son-in-law and burning their farm. Refusing to bow to pressure, Campbell and his lawyers continued to pursue the case after his release. ${ }^{90}$

The Tribunal issued its merits judgment in November 2008. The decision was bold in multiple respects. First, with regard to jurisdiction, Zimbabwe argued that the references to 'human rights, democracy and the rule of law' and non-discrimination in the SADC Treaty's Principles and General Undertakings clauses ${ }^{91}$ could not be adjudicated until the adoption of a separate protocol. ${ }^{92}$ Since the member states had adopted other protocols clarifying the issues to be referred to the Tribunal or handled in other ways,${ }^{93}$ the judges could reasonably have declined jurisdiction. Instead, they summarily rejected Zimbabwe's argument. ${ }^{94}$

Turning to the merits, the Tribunal ruled that Zimbabwe had violated the white landowners' rights in three respects - denying access to justice, discriminating on the basis of race and failing to provide fair compensation. The first of these holdings was the least controversial. Had the Tribunal confined its decision to the access to justice issue, its ruling would have been a mostly symbolic victory for the plaintiffs. The two other violations, however, struck at the heart of Mugabe's land redistribution programme. In defending its land reform programme against the non-discrimination claim, the government cited the need to remedy inequities that persisted after independence. That most owners of large agricultural lands happened to be white could not, therefore, 'be attributed to racism but [rather to] circumstances brought about by colonial history'. ${ }^{95}$

88 SADC Tribunal, Gideon Stephanus Theron and 7 Others v. Zimbabwe, Case No. SADC (T) 03/08, 04/08 and 06/08, 28 March 2008 (application to intervene in Campbell case; granting intervention to 77 white farmers and ordering injunctive relief), available at www.worldcourts.com/sadct/eng/decisions/2008.03.28_Theron_v_Zimbabwe.htm (last visited 16 March 2016).

89 SADC Tribunal, Campbell v. Zimbabwe (Interim Ruling), Case No. SADC (T) 2/2007, 17 December 2007, at 8, available at https://assets.documentcloud.org/documents/217670/campbell-v-zimbabwe-case-no2-2007-ruling.pdf (last visited 16 March 2016).

90 According to newspaper accounts, Campbell later died from injuries he sustained during the kidnapping. D. Herbstein, 'Mike Campbell Obituary', The Guardian (24 April 2011), available at www.theguardian. com/world/2011/apr/24/mike-campbell-obituary (last visited 16 March 2016).

91 SADC Treaty, supra note 80, Arts 4(c), 6(2).

92 Campbell, supra note 84, at 23. During the drafting of the SADC Protocol, supra note 83, an expert panel considered, but ultimately rejected, the 'inclusion of human rights in the mandate of the SADC Tribunal'. However, the panel also noted that the SADC already had 'a more general human rights mandate'. F. Viljoen, International Human Rights Law in Africa (2012), at 492.

93 SADC Overview: Protocols, available at www.sadc.int/about-sadc/overview/sa-protocols/ (last visited 16 March 2016). For example, the SADC Trade Protocol envisions a World Trade Organization-style dispute settlement procedure administered by the Tribunal's Registrar but involving ad hoc panels rather than adjudication by the Tribunal. South African Development Community Consolidated Protocol on Trade (2012), available at https://tis.sadc.int/files/6213/2808/8365/CONSOLIDATED_PROTOCOL_ON_ TRADE_vers_30-01-2012.pdf (last visited 16 March 2016), Annex VI.

95 Ibid., at 44. 
The judges disagreed, finding that the land reform programme had a disparate impact on white farmers that was 'unjustifiable and disproportionate' as well as 'arbitrary and ... based primarily on considerations of race' ${ }^{96}$ Redistribution might be legitimate, the judges reasoned, if lands were 'distributed to poor, landless, and other disadvantaged and marginalized groups'. But the Tribunal found that 'the spoils of expropriation' had been distributed primarily to members of the ruling party. ${ }^{97}$ The Tribunal next ruled that international law required the government 'to protect the possession, occupation and ownership of' white farmers still on their land and to compensate those whose lands it had already seized. Moreover, Zimbabwe could not rely on its Constitution to avoid these obligations. ${ }^{98}$

The political fallout of the Campbell judgment was immediate. Mugabe showed nothing but contempt for the decision and the Tribunal. His statement to supporters a few months after the judgment is illustrative: 'Some farmers went to the SADC [T]ribunal in Namibia, but that's nonsense, absolute nonsense, no one will follow that ... We have courts here in this country, that can determine the rights of people. Our land issues are not subject to the SADC [T]ribunal. ${ }^{99}$ Faced with government intransigence, the white farmers returned to court. Although Zimbabwe did not participate in the proceedings, the SADC judges found sufficient evidence to hold the state 'in breach, and contempt' of the Campbell judgment and reported this finding to the SADC Summit - the community's highest political body - for further action. ${ }^{100}$ The June 2009 contempt ruling galvanized Mugabe into action.

Events unfolded with lightning speed over the next few weeks. In August 2009, the Tribunal's president presented the Summit with a finding of Zimbabwe's non-compliance, as required by Article 32 of the Tribunal's Protocol. This provision requires member states and community institutions to take 'all measures necessary to ensure execution of decisions', ${ }^{101}$ yet there was great uncertainty regarding what such measures might be. ${ }^{102}$ The Summit referred the legal question to a Meeting of the Minsters of Justice and Attorneys General.

Meanwhile, Mugabe tasked Patrick Chinamasa, his Minister of Justice and Legal Affairs, to develop a political strategy to challenge the Campbell litigation and discredit

96 Ibid, at 53. The racial discrimination finding was disputed by Judge Tshosa, who concluded that whites were inevitably affected more significantly by the government's land redistribution policy because they controlled most of the country's agricultural land. For further discussion, see Achiume, 'Lawmaking, Geopolitical Dissonance, and the Authority of International Courts: Lessons from the SADC Tribunal', in K. Alter, L. Helfer and M. Madsen (eds), International Court Authority (forthcoming).

97 Campbell, supra note 84, at 54.

98 Ibid., at 58.

99 C. Chinaka, 'Mugabe Says Zimbabwe Land Seizures Will Continue', Mail and Guardian (28 February 2009), available at http://mg.co.za/article/2009-02-28-mugabe-says-zimbabwe-land-seizures-will-continue (last visited 16 March 2016).

100 SADC Tribunal, Campbell and Another v. Republic of Zimbabwe, SADC (T) 03/2009, 5 June 2009, available at www.saflii.org/sa/cases/SADCT/2009/1.html (last visited 16 March 2016).

101 SADC Protocol, supra note 83, Art. 32.

102 Interview with former SADC Tribunal official (date and location withheld). SADC Treaty, supra note 80, Art. 33 authorizes the Summit to impose sanctions for persistent non-compliance. This provision has never been invoked, however. 
the SADC Tribunal. Chinamasa arrived at the Meeting of Minsters of Justice and Attorneys General with a 42-page memorandum arguing that the Tribunal had never been properly constituted. The common view, later upheld by an outside legal expert, was that the 2000 Protocol creating the Tribunal entered into force when it was adopted by three quarters of the Heads of State of the SADC, including Zimbabwe, as provided for in the 1991 Treaty. ${ }^{103}$ Chinamasa argued that the Protocol was not binding because two thirds of the member states, including Zimbabwe, had never ratified the Protocol. As a result, he argued, all SADC Tribunal rulings were null and void, and the member states were under no obligation to comply with them. ${ }^{104}$ This unexpected claim threw the meeting into disarray, delaying any discussion of whether or how to sanction Zimbabwe's non-compliance. ${ }^{105}$ A week later, Chinamasa took the next logical step, informing the Registrar that Zimbabwe "would not appear before [the Tribunal] anymore, and neither would Government be bound by any decisions already made or future ones emanating from there'. ${ }^{106}$

Campbell's lawyers and the Tribunal's supporters rushed to defend the judges and their rulings. ${ }^{107}$ With the competing legal arguments now out in the open, the other member states had to decide how to respond to Zimbabwe's attack. While 'Chinamasa travelled to the regional capitals' to lobby other governments, ${ }^{108}$ the SADC Council of Ministers 'was tasked with responding to Zimbabwe's objections' at the next SADC Summit scheduled for August 2010. ${ }^{109}$ A month before that meeting, the Tribunal upped the political stakes by issuing another contempt ruling against Zimbabwe and again referring the country's treaty violations to the Summit. ${ }^{110}$

We interviewed a former SADC judge about the contempt orders, asking whether the Tribunal members in fact expected the Summit to enforce the Campbell judgment. At the

103 Ibid., Art. 36(1).

104 Execution and Enforcement of Judgments of the SADC Tribunal, Opinion of the Government of the Republic of Zimbabwe on Issues Relating to International Law Raised at the Meeting of Ministers of Justice/Attorneys-General, Pretoria, South Africa, July 30-31 2009, 31 August 2009.

105 Interview with Former SADC Tribunal Official (date and location withheld).

106 M. Sasa, 'Zim Pulls out of SADC Tribunal', Herald (Zimbabwe, 2 September 2009) (quoting letter of 7 August 2009), available at www.zimbabwesituation.com/sep3_2009.html (last visited 16 March 2016).

107 E.g., Southern African Litigation Centre, Re: Submissions made by the Minister of Justice, Zimbabwe, as to the Legal Competence of the SADC Tribunal, The Enforceability of its Decisions, and the Legal obligations of the Zimbabwean Government, 22 September 2010, available at https://groups.yahoo.com/neo/ groups/zimsite/conversations/topics/40556 (last visited 16 March 2016).

108 Nathan, 'Solidarity Triumphs over Democracy: The Dissolution of the SADC Tribunal', 57 Development Dialogue (2011) 123, at 130, available at http://repository.up.ac.za/handle/2263/19451?show=full (last visited 16 March 2016); see also Fritz, Up in Smoke, SAFPI Policy Brief No. 11 (September 2012), at 2, available at http://osf.org.za/wp-content/uploads/2015/08/Up-in-smoke-The-SADC-Tribunal-andRule-of-Law-in-the-region.pdf (last visited 16 March 2016).

109 Southern Africa Litigation Centre (SALC), Implications of the Decision to Review the Role, Functions and Terms of Reference of the SADC Tribunal: An Opinion (SALC Opinion) (undated, but likely early 2011), para. 2, available at www.africancourtcoalition.org/images/docs/research-papers/SADC $\% 20$ Opinion\%20-\%20final.pdf (last visited16 March 2016). We have not been able to find this study, and it appears not to have been completed in time for the Summit.

110 SADC Tribunal, Fick and Another v. Republic of Zimbabwe, SADC (T) 01/2010, 16 July 2010, available at www.saflii.org/sa/cases/SADCT/2010/8.html (last visited 16 March 2016). 
time, Mugabe was brazenly ignoring a power-sharing deal that the SADC had brokered. If the sub-region's political leaders had not sanctioned the president for violating an accord that they had publicly endorsed, it seems unimaginable that they would enforce a ruling that overturned his signature land redistribution policy. For the judges, however, the law provided a simple answer: '[T] he applicant was given a remedy; it needed to be enforced.' 111

At the August 2010 Summit, Mugabe 'threatened to block any discussion of Zimbabwe and its human rights record'. ${ }^{112}$ Although there is no public record of the Summit proceedings, it seems that several member states opposed Zimbabwe's actions. Officially, a compromise was reached whereby the Summit decided to hire an outside consultant to undertake 'a review of the role, functions and terms of reference of the SADC Tribunal', to be concluded within six months. ${ }^{113}$

On its face, this was a plausible way to address the Tribunal's unsettled legal status. Yet the compromise must be understood in light of the decisions that the Summit did not take - the renewal of five SADC judges whose terms were about to expire, and the replacement of the Zimbabwean judge whom Mugabe had withdrawn in 2009. The SADC Secretariat had placed these issues on the Summit's agenda. By taking no action, the heads of state left the Tribunal with only four judges - below the minimum required to accept new complaints. ${ }^{114}$

The failure to reappoint the judges was a deliberate back-up strategy to Zimbabwe's frontal assault on the Tribunal and the Campbell rulings. Mugabe first blocked discussion of, and later derailed, a Minsters of Justice and Attorneys General recommendation to reappoint the judges whose terms had expired. This strategy exploited an ambiguity in the SADC Tribunal Protocol - its silence regarding the failure to renew or reappoint sitting judges. ${ }^{115}$ By refusing to agree to renew or reappoint the judges - acts that required the consent of all member states - Mugabe ensured that the Tribunal would eventually cease to function even if its legal mandate remained intact.

Initially, however, the outcome of the 2010 Summit was only a partial victory for Zimbabwe, since the remaining SADC judges were still in office and were pressing for compliance with the Campbell judgment. To counter this threat, Mugabe and Justice Minister Chinamasa spun the Summit's decision in the press as a formal suspension of the Tribunal. ${ }^{116}$ SADC Executive Secretary Tomaz Salomão attempted to thwart this

111 Interview with Former Judge of the SADC Tribunal, Gaborone, Botswana (9 August 2013).

112 Cowell, 'The Death of the Southern African Development Community Tribunal's Human Rights Jurisdiction', 131 Human Rights Law Review (2013) 153, at 161.

113 Final Communiqué of the 30th Summit of SADC Heads of State and Government (19 August 2010), para. 32.

114 SALC Opinion, supra note 109, paras 4-5, 22-23.

115 SADC Protocol, supra note 83, Art. 4(6) provides that judicial vacancies shall be filled 'within three (3) months of the vacancy occurring', but it is silent on what happens if a judge's term expires and the vacancy is unfilled. The EAC Treaty leaves this issue to 'be determined by the Summit on the recommendation of the Council', EAC Treaty, supra note 30, Arts 25(3), 25(5). By contrast, as noted above, the ECOWAS Court Protocol provides that a judge shall remain in office until a successor is appointed.

116 C. Zvayi, 'Southern African Development Community Tribunal Suspended', The Herald (17 August 2010), available at http://panafricannews.blogspot.com/2010/08/south-african-development-community.html (last visited 18 March 2016); 'Mugabe Insists SADC Tribunal "Has Been Suspended”, 23 August 2010, cited in Nathan, supra note 79, at 878, n. 45. 
disinformation campaign by reiterating the Summit's official position: 'No one took a decision to suspend the Tribunal. What was said is that the Tribunal's role [and] responsibility has to be reviewed by professionals and experts to come up with clear recommendations. ${ }^{117}$

With charges and counter-charges flying, the next act in the backlash drama began to unfold - the Summit-mandated review of the Tribunal's powers and terms of reference. The Secretariat issued a tender, awarding a contract to the World Trade Institute. ${ }^{118}$ The report, written by Cambridge University professor Lorand Bartels, categorically rejected Zimbabwe's legal arguments, concluding that the Tribunal was validly constituted and authorized to review human rights complaints from private litigants. The report also recommended that the Protocol be amended to presumptively reappoint Tribunal judges and officials unless the Summit chose to replace them. ${ }^{119}$ The Minsters of Justice and Attorneys General later endorsed this proposal as well as a recommendation to reappoint the existing SADC judges. ${ }^{120}$

Contemporaneous accounts suggest that the member states were divided over how to proceed. The Secretariat organized an Extraordinary Summit, which was held in May 2011, at which the Tribunal was the sole agenda item. Knowledge of the meeting was withheld from Tribunal officials, who were notified only 48 hours in advance. ${ }^{121}$ At the meeting, Zimbabwe reiterated its opposition to the status quo. It also derailed the Minister of Justices and Attorneys General recommendation to reappoint the judges. The Summit's final communiqué directed the ministers to prepare a fresh report proposing 'amend[ments to] the relevant SADC legal instruments' by August 2012. The communiqué also purported to 'reiterate[] the moratorium on receiving any new cases or hearings of any cases by the Tribunal' and declined to reappoint or replace any SADC judges. ${ }^{122}$ The formal minutes of the meeting have never been released, and it is uncertain whether the Summit in fact made an affirmative decision to suspend the Tribunal and, if it did, whether such a decision would be legal. ${ }^{123}$

117 'SADC Tribunal Not Suspended: Salamao', The Zimbabwean (19 August 2010), available at http://www. thezimbabwean.co/2010/08/sadc-tribunal-not-suspended-salamao/ (last visited 18 March 2016).

118 Email correspondence with Lorand Bartels (14 April 2015).

119 L. Bartels, Review of the Role, Responsibility and Terms of Reference of the SADC Tribunal: Final Report (2011), at 6, available at www.scribd.com/doc/115660010/WTIA-Review-of-the-Role-Responsibilitiesand-Terms-of-Reference-of-the-SADC-Tribunal-Final-Report (last visited 17 March 2016). The report also recommended a series of amendments to clarify ambiguities and resolve conflicts across SADC legal instruments while maintaining the Tribunal's broad jurisdiction and access rules (at 70, 82-87).

120 Interview with SADC Tribunal Official (date and location withheld).

121 Justice Ariranga Pillay, former President of SADC Tribunal, SADC Tribunal Dissolved by Unanimous Decision of SADC Leaders (Pillay Speech), 11 July 2011, available at www.africancourtcoalition.org/ images/docs/subregionalcourts/sadctribunal/SADC\%20Tribunal\%20Dissolved\%2020110718.pdf (last visited 17 March 2016).

122 Communiqué of the Extraordinary Summit of SADC Heads of State and Government, 20 May 2011, paras $7-8$.

123 Interview with SADC Tribunal Official (date and location withheld). See, e.g., D. Steinmann, 'Summit Assigns Itself Jurisdictional Powers It Does Not Have', Namibia Economist (17 August 2012), available at https://economist.com.na/2548/editors-desk/summit-assigns-itself-jurisdictional-powers-it-does-nothave/ (last visited 17 March 2016). 
During the next 15 months, human rights attorneys, NGOs and the judges themselves - all of whom had been shut out of the SADC decision-making processes $^{124}$ - attempted to mobilize to save the Tribunal. They faced an uphill battle. The Secretariat had become increasingly wary of transparency and of civil society groups. It declined to release the Bartels report, leading the Tribunal's backers to post it on the Internet. ${ }^{125}$ The intensely political environment, which included quietly voiced accounts of Secretariat officials doctoring official communiqués to, in effect, supplant decisions taken by the Summit, created an atmosphere in which the SADC employees became reluctant to talk or share accounts of what had in fact occurred.

To highlight the Tribunal's emasculation, the SADC judges gave speeches, the NGOs held conferences, drafted resolutions and press statements and the attorneys prepared legal briefs outlining objections to the suspension. ${ }^{126}$ Partly in response to this 'heavy lobbying', the Ministers of Justice and Attorneys General approved a revised draft Protocol that offered a compromise. ${ }^{127}$ The draft preserved the right of private litigants to challenge legal violations and added an appeals chamber. But it also narrowed the Tribunal's standing rules and made its human rights jurisdiction contingent on the adoption of an additional legal instrument. ${ }^{128}$ On the crucial issue of the Campbell case, however, the draft Protocol was unequivocal: 'All actions, decisions, judgments and other administrative acts undertaken pursuant to the 2000 Protocol ... shall remain valid and in force. ${ }^{129}$

124 E.g., Letter Submitted to Honorable Ministers of Justice and Attorneys General re: Amendments to the Protocol Establishing the SADC Tribunal (1 June 2012), at 4, available at www.africancourtcoalition. org/images/docs/subregionalcourts/sadctribunal/NGOs\%20Letter\%20to\%20SADC $\% 20$ Ministers $\% 20$ of\%20Justice\%20and\%20Attorneys\%20General.pdf (last visited 17 March 2016) (complaining that it has been virtually impossible for us as SADC NGOs even to attend the SADC Summit or Ministers of Justice meetings on the sidelines').

125 H. Melber, Promoting the Rule of Law: Challenges for South Africa's Policy, Open Society Foundation for South Africa SAFPI Commentary No. 5, 13 August 2012, at 9, available at http://osf.org.za/wp-content/ uploads/2015/08/Promoting-the-rule-of-law-Challenges-for-South-Africas-policy.pdf (last visited 17 March 2016).

126 See, e.g., Resolutions of SADC Lawyers, Judges and Rule of Law Advocates adopted at the 2nd Regional Legal Consultative Conference on the Review of the SADC Tribunal, 28 July 2011, available at www. africancourtcoalition.org/images/docs/subregionalcourts/sadctribunal/2nd\%20Consultative $\% 20$ conference $\% 20$ on $\% 20$ the $\% 20$ review $\% 20$ of $\% 20$ SADC $\% 20$ Tribunal $\% 20-\% 20$ Resolutions.pdf (last visited 17 March 2016); Pillay Speech, supra note 121; Submission Regarding Amendments to the SADC Tribunal Protocol: Relating to Access Provisions, the Relationship with Superior National Courts and Its Human Rights Mandate (undated, but likely 1 June 2012), available at www.africancourtcoalition. org/images/docs/subregionalcourts/sadctribunal/NGOs $\% 20$ Submission $\% 20-\% 20$ Access $\% 20$ and $\% 20$ jurisdiction\%20issues\%20at\%20SADC\%20Tribunal.pdf (last visited 17 March 2016).

127 F. Nijini, 'Zimbabwe Wins Key Battle at Maputo Summit', Southern Times (20 August 2012), available at http://southernafrican.news/2012/08/20/zimbabwe-wins-key-battle-at-maputo-summit/ (last visited 17 March 2016).

128 Draft Protocol on Tribunal in the Southern African Development Community 2000 As Amended, SADC/ MJ/2/2012/4, 19 June 2012, Art. 15, available at www.osisa.org/sites/default/files/draft_sadct_protocol.pdf (last visited 17 March 2016).

129 Ibid., Art. 58. 
Once again, Mugabe used the Summit to defeat the compromise. Zimbabwe could have settled for cabining the Tribunal's human rights powers or appointing a new set of politically timid judges. Instead, Mugabe lambasted the Ministers of Justice proposal, renewing his claim that Western powers were stage-managing the SADC review process to target the country's land redistribution policies. ${ }^{130}$ Multiple sources suggested that the Summit leaders decided to again return the issue of the Tribunal's future to the Ministers of Justice and Attorneys General for reconsideration. The signed Summit decisions have never been circulated, however, and multiple sources told us that Zimbabwe worked with the Secretariat to doctor the official communiqué. The sole public record of the meeting reflects an unequivocal victory for Zimbabwe - a call for a new Protocol that confines the Tribunal's mandate to the 'interpretation of the SADC Treaty and Protocols relating to disputes between Member States' ${ }^{131}$

While the SADC insiders debated how they should respond to the hijacked Summit, Mugabe's continued refusal to appoint Tribunal judges or staff had, on its own, effectively killed the sub-regional court. As a government official in Botswana explained, by mid-2013 the contracts of the judges and staff had run out, "[s]o now there is no SADC Tribunal'. ${ }^{132}$ This fait accompli gave Zimbabwe the upper hand in the negotiations to reconstitute the Tribunal stripped of private litigant access.

The Summit's official communiqué devastated civil society groups. ${ }^{133}$ Advocates challenged the Tribunal's suspension before the African Commission on Human and Peoples' Rights, but the Commission rejected the complaint. ${ }^{134}$ In August 2014, the SADC Summit adopted the new protocol, which removes the right of private access, and it permits member states to withdraw from the Tribunal's jurisdiction by giving 12 months notice. ${ }^{135}$ Nine African leaders, including Mugabe, signed the new instrument at the Summit, while civil society groups, Campbell's lawyers and a former SADC judge decried the creation of a 'toothless and useless' sub-regional court that is unlikely to hear any cases. ${ }^{136}$ Meanwhile, lawyers for Mike Campbell attempted to enforce the Tribunal's rulings in South African courts, eventually collecting modest damages from Zimbabwe. ${ }^{137}$

130 Nijini, supra note 127.

131 Final Communiqué of 32nd Summit of SADC Heads of State and Government, 18 August 2012, para. 24.

132 Interview with Official of the Botswana Trade Ministry, Gaborone, Botswana (8 August 2013).

133 R. Lee, SADC Leaders Destroy SADC Tribunal, Open Society Initiative for Southern Africa, 20 August 2012, available at www.osisa.org/law/regional/sadc-leaders-destroy-sadc-tribunal (last visited 17 March 2016).

134 A. Bell, 'Top African Court "Powerless” to Reinstate SADC Tribunal', SW Radio Africa (6 March 2014), available at www.tralac.org/news/article/5511-top-african-court-powerless-to-reinstate-sadc-tribunal. html (last visited 17 March 2016).

135 Draft Protocol of the SADC Tribunal, 18 August 2014, Art. 50 (copy on file with authors); see also G. Erasmus, The New Protocol for the SADC Tribunal: Jurisdictional Changes and Implications for SADC Community Law, TRALAC Working Paper No. US15WP/2015 (January 2015), available at www.tralac. org/publications/article/6900-the-new-protocol-for-the-sadc-tribunal-jurisdictional-changes-andimplications-for-sadc-community-law.html\#downloads (last visited 17 March 2016).

136 Interview with Former Judge of the SADC Tribunal, Gaborone, Botswana (9 August 2013).

137 The lawyers secured a favourable ruling from the South African Constitutional Court that forced Zimbabwe to make a \$20,000 payment to avoid execution on property it owned in South Africa. D. Smith, 'Zimbabwe Government's U-Turn on White Farmers', Mail and Guardian (20 September 2013), available at http://mg.co. za/article/2013-09-20-00-zimbabwe-governments-u-turn-on-white-farmers/ (last visited 17 March 2016). 


\section{Comparing the Three Backlashes: Similarities and Differences}

The three backlash attempts we analyse highlight the difficulty of collectively sanctioning international courts for politically embarrassing rulings, even for governments that are weakly committed to judicial independence. The barriers to carrying out backlash proposals are political and institutional. Politically, even governments that share concerns about controversial adverse international court rulings may be reluctant to openly support national leaders who commit human rights abuses against their own citizens. Institutionally, inertia is on the side of international courts - blocking change is easier than reaching consensus in favour of altering the status quo. Before offering our own explanation of the divergent outcomes of the three court backlash campaigns, we first identify institutional and power-based similarities and differences that allow us to eliminate or at least diminish alternative explanations. Table 1 compares these features across the three cases.

For all three sub-regional communities, membership brought with it the compulsory jurisdiction of a sub-regional court. Unilateral withdrawal from the Court's jurisdiction was not a legally viable option without exiting the community as a whole. All three courts also provided direct access to private litigants alleging state violations of community treaties, which expressly or implicitly incorporated references to human rights. In addition, all three international courts were young institutions that began to function in the 2000s, and all three backlashes responded to adverse rulings issued in the first few years of each court's operation.

Perhaps most importantly, each sub-regional community requires consensus to modify the Court's jurisdiction and access rules. The give and take required to reach consensus affects whether court curbing campaigns succeed and to what extent. In East Africa, for example, the opposition of Tanzania and Uganda to Kenya's initial push to eliminate the EACJ was crucial to moderating the backlash. The need to obtain consensus may also explain why the Gambia touted its campaign against the ECOWAS Court as a relatively modest judicial reform proposal. It is also possible, however, for one state to repeatedly block consensus, transforming the decision-making rule into a de facto unanimity requirement. Zimbabwe's dogged refusals to acquiesce in reforms that fell short of removing private party access to the SADC Tribunal illustrates an effective use of this strategy.

Table 1 reinforces a key finding that emerges from the three narratives - the government leading each backlash campaign had to expend considerable political capital and effort to achieve its objectives, and it did not succeed immediately or in full. For example, the aggrieved governments failed to pressure sub-regional judges to revise or withdraw their decisions, and they could not convince other member states to eliminate the tribunal or overturn its contested legal rulings.

The swiftness of the EAC backlash stands out, however. Kenya's partial success in restructuring the Court was aided by the small number of geographically close member states whose leaders meet regularly and discuss sub-regional integration issues outside of official decision-making venues. Zimbabwe's effort to strip private litigant 


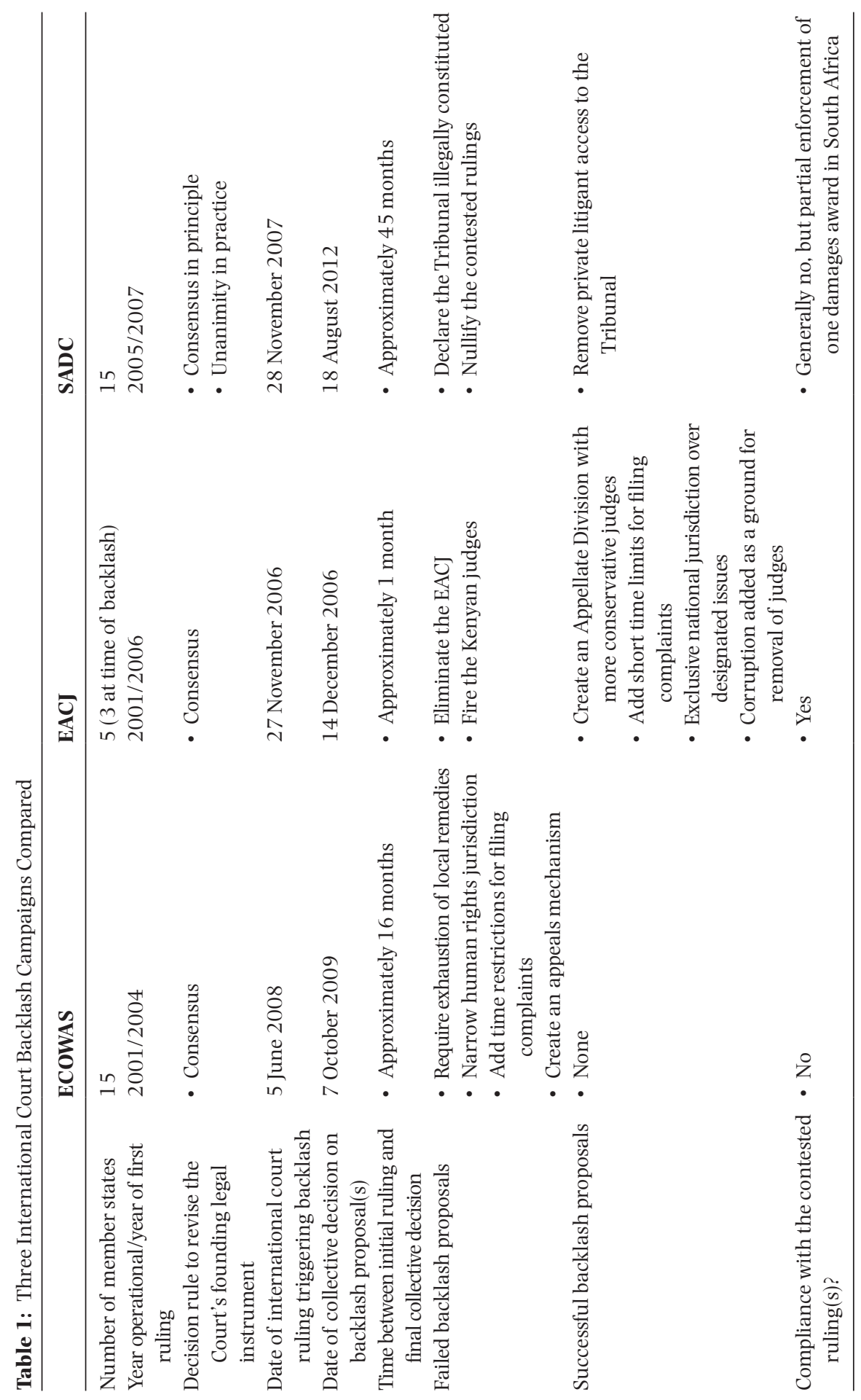

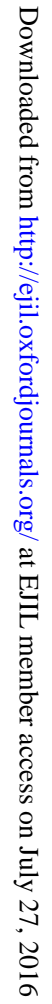


access to the SADC Tribunal illustrates the other end of the time spectrum. The consensus rule required to revise the Tribunal's mandate repeatedly generated compromise proposals that Zimbabwe thwarted. Mugabe's 'plan B' - starving the Tribunal by blocking judicial renewals and appointments - was a multi-year strategy. However, once the sub-regional court was no longer operational, Zimbabwe could dictate the terms of its resurrection and insist on stripping private party access.

Another difference among the three cases is the economic and political power of the country orchestrating the backlash. Kenya and Nigeria are the undisputed economic and political hegemons in East and West Africa, respectively. Zimbabwe's economy is in disarray, but its political influence in the SADC is elevated by Mugabe's prominence as one of Africa's longest-serving leaders and his anti-colonial bona fides. The clear outlier among the three countries is the Gambia, which is small in size, population and economic clout.

Might the failure of the ECOWAS Court backlash thus be explained by the Gambia's relatively weak status in West Africa? No doubt, opposing President Jammeh was less costly than challenging leaders of more powerful ECOWAS nations. ${ }^{138}$ The lack of popular support for the Gambian government in the region also facilitated opposition to its proposals. These factors are not decisive, however. Prior to issuing the two judgments that enraged the Gambia, ECOWAS judges had found other West African governments in violation of their citizens' human rights. Moreover, many of the then pending cases were against Nigeria, which had previously objected to the Court's attempt to intervene in a contested election in that country. ${ }^{139}$ Moreover, the Gambia's reforms were the most modest of the three backlash proposals, and some of them were recently revived in the guise of genuine improvements to the Court. ${ }^{140}$ For all of these reasons, it would have been relatively uncontroversial for other West African governments to accede to the Gambia's proposals.

Another plausible, but ultimately unhelpful, explanation for the divergent backlash outcomes concerns the process for appointing sub-regional judges. The law and politics of appointments may explain the extent to which international court judges are bold or timid, but they cannot explain whether court-curbing campaigns succeed or fail. Stacking an international court with pro-government judges following a disfavoured ruling might, however, be a way to clip a court's wings. Yet none of the three governments pursued this strategy. A partial exception is the EACJ, whose member states have appointed somewhat more conservative judges to the Appellate Division. In the decade since the backlash, however, the appellate judges have not appreciably constrained the EACJ's foray into human rights.

138 See Viljoen, supra note 92, at 499 (referring to the Gambia's status as 'one of the smallest and least powerful states in ECOWAS' as helping to defeat its proposal).

139 For further discussion, see Alter, Helfer, and McAllister, supra note 1, at 758-760.

140 ECOWAS Retreat Adopts Recommendation for Setting Up an ECOWAS Court Appellate Body and Sub-Registries, Press Release, March 2013 available at www.courtecowas.org/site2012/index. php?option $=$ com_content\&view $=$ article $\&$ id $=214$ : ecowas-retreat-adopts-recommendation-for-settingup-an-ecowas-court-appellate-body-and-sub-registries (last visited 17 March 2016). 
A final difference pertains to the subject matter of the contested rulings. The decisions against the Gambia - disappearance and torture of dissident journalists - were unequivocal human rights abuses that no government openly defended. The EALA elections case, in contrast, involved a dispute over the boundary between community and domestic law, a first-impression issue of jurisdiction that was amenable to good faith disagreement. The challenge to Zimbabwe's land rights regime was by far the most incendiary of the three suits. All post-colonial societies struggle with the fraught legacy of highly concentrated property ownership. Thus, there was much sympathy among regional leaders when Zimbabwe argued that 'if it happens to us, it happens to you next'. ${ }^{141}$

These subject matter differences cannot, however, explain why the Kenyan and Zimbabwean backlashes succeeded in part. Land rights may well be a third rail of post-colonial politics in Africa. But without Mugabe's intransigence, one of the many compromise proposals could well have succeeded. In fact, the SADC Tribunal's supporters repeatedly convinced the region's Ministers of Justice and Attorneys General to endorse reforms that retained private litigant access. Also, in interviews SADC insiders reported that until the new protocol's adoption, Summit decisions had supported returning the issue to the ministers for further review and a possible compromise. However, Mugabe's strategy of blocking these proposals while starving the Tribunal of judges and staff eventually forced the other member states to accept stripping private access as the price to be paid for resurrecting the subregional court.

\section{Explaining the Divergence in Backlash Outcomes: The Role of Community Secretariats, Civil Society Groups and Sub-Regional Parliaments}

The difficulty of successful backlash suggests a clear strategy for international court supporters: calling for adherence to established decision-making procedures. Delaying and publicizing sanctioning campaigns allows tempers to cool, exposes the ulterior motives of seemingly benign proposals and shames other governments from tacitly supporting court-curbing efforts. In addition, by insisting that states follow these procedures, secretariats, civil society groups and regional parliaments can slow down sanctioning initiatives, enhance transparency and create opportunities to rally against backlash proposals.

This section examines the varying ability of these actors to mobilize to defeat the three backlash campaigns. We focus on the political and institutional culture within the community secretariats and their relationships to civil society groups as well as the groups' organizational capacity and resources. In East Africa, the EALA also provided an additional source of support for the court, something that was lacking in the other two sub-regions.

141 Interview with a Former Official of the SADC Lawyers Association, Gaborone, Botswana (9 August 2013). 


\section{A Sub-Regional Secretariats as Brokers in Managing International Court Backlash}

The secretariats in each sub-region are comprised of a chief executive - a political appointee - supported by a professional staff responsible for legal and policy matters within the community's purview. Secretariats organize meetings of government officials, set agendas, coordinate logistics and prepare official documents. They also advise states and political appointees on draft legislation and assist with the reviews of community institutions. On paper, these decisions are matters of public record. In reality, community websites are often out of date, and hard copies are unavailable. Knowledge of these decisions - and opportunities for input by civil society - thus depend on how forthcoming Secretariat officials are in disseminating information to interested stakeholders.

The political culture and professionalization within the secretariats determines whether these bodies exert independent influence within an overarching structure of state power. These factors affect the willingness and ability of Secretariat officials and staff to meaningfully defend community interests, including by engaging civil society groups. The expectations of member states and political appointees shape this culture. Where governments expect secretariats to be concierges or helpmeets, officials and staff become less open and transparent, excluding civil society groups and acquiescing to extra-legal pressures to ignore community decision-making procedures.

In West Africa during the years of the backlash, the staff of the ECOWAS Secretariat had earned the member states' trust and thus had considerable autonomy to carry out its activities. For example, the Legal Affairs Department spearheaded the initiative to give the ECOWAS Court a human rights jurisdiction. When governments expressed concern about some early court decisions, the Secretariat facilitated the creation of an ECOWAS Judicial Council that used a merit-based process for selecting judges.

With regard to the Gambian backlash, Secretariat officials followed procedures that required informing ECOWAS judges about court reform proposals, a disclosure that enabled the judges to reach out to allies to oppose the initiatives. ${ }^{142}$ Officials also gave advance notice about key meetings, enabling civil society groups to attend and present their views. The presence of NGOs at these meetings signalled to governments that their actions were being scrutinized by networked groups who could quickly disseminate the decisions. The ECOWAS Secretariat thus influenced the fate of the backlash proposals through information sharing and indirect coalition building.

The situation in the EAC was quite different. The Secretariat seemingly did not object when Kenya scheduled a series of rushed extraordinary meetings at which national political leaders discussed the EACJ's fate. In fairness, the Secretariat faced immense pressure from Kenya, whose top officials - incensed at the EACJ's injunction in the Nyong'o case - were highly motivated, called meetings outside normal channels and drafted treaty amendments to clip the Court's wings. Moreover, Uganda and Tanzania - although unwilling to kill the EACJ - supported or at least acquiesced in 
Kenya's more moderate reform proposals, limiting any manoeuvring room Secretariat officials may have had to slow down the backlash campaign.

Yet the EAC Secretariat refrained from following mandatory procedures that could have bolstered support for the sub-regional court. In particular, we found no evidence that officials informed or sought the input of civil society actors regarding Kenya's backlash proposal, notwithstanding express community rules requiring such consultation. ${ }^{143}$ On the contrary, we were told that the Secretariat - and, in particular, its Office of Legal Counsel - generally avoided, or put off interactions with, civil society groups agitating to strengthen the community legal order. ${ }^{144}$

It is not surprising that the EAC officials viewed their mandate primarily through the prism of member state interests. Until recently, government lobbying rather than a competitive, merits-based process was used to recruit professional staff. ${ }^{145}$ Further, the Secretariat reports to the Council of Ministers, the community's top political body that represents member state interests. The control exercised by the Council has deterred the Secretariat from expanding its autonomy or even from exercising the authority expressly conferred by the EAC Treaty. ${ }^{146}$ In sum, EAC Secretariat officials did not attempt to leverage NGOs that promote human rights and the rule of law in East Africa as a counterweight to Kenya's backlash proposal. Perhaps ironically, the Court itself has done a much better job of mobilizing support from civil society. ${ }^{147}$

In the SADC, the toxic political climate makes it difficult to assess the extent of the Secretariat's efforts to protect the Tribunal from Mugabe's wrath. Executive Secretary Salomão countered early attempts by Zimbabwe to spin a modest Summit decision as a vindication of the country's more radical position, and Secretariat officials seemingly worked in good faith with the Ministers of Justices and Attorneys General to craft compromise solutions, including a new draft protocol for the Tribunal. However, as Mugabe escalated the confrontation and blocked compromise proposals that would have partly preserved private access to the Tribunal, the Secretariat became less forthcoming in sharing information with Tribunal supporters and more closely aligned with the backlash campaign.

143 See D. Deya, The Place of Civil Society in the Eastern African Community, Outline for a Session in the Kitua Cha Katiba Intensive Seminar on the East African Community: Organs, Institutions and Procedures (on file with authors).

144 Interview with Human Rights Advocate M, Nairobi, Kenya (1 August 2013).

145 See A. Odhiambo, 'Five Kenyans Short-Listed for Top EAC Jobs', Business Daily Africa (18 January 2015), available at www.businessdailyafrica.com/Five-Kenyans-shortlisted-for-top-EAC-jobs//539546/2593728/-/14rpt43/-/index.html (last visited 17 March 2016).

146 EAC Treaty, supra note 30, Art. 71(1) provides: 'In the performance of their functions, the staff of the Community shall not seek or receive instructions from any Partner State. ... They shall refrain from any actions which may adversely reflect on their position as international civil servants and shall be responsible only to the Community.'

147 According to the first EACJ Registrar, the judges 'boldly went around the region meeting its stakeholders including bar associations, business communities, civil societies, law reform commissions and Attorney Generals'. J. Ruhusinga, Litigation in the East African Court of Justice, Paper Presented to the East African Law Society, African Executive, 12-19 July 2006, available at www.africanexecutive.com/modules/magazine/articles.php? article=794 (last visited 17 March 2016). 
The SADC Secretariat also circumvented or ignored applicable procedures. Officials denied funds to cover the travel and lodging expenses of SADC judges, limiting their ability to convene at the Tribunal. Officials also failed to announce upcoming meetings and decisions. For example, the Tribunal's president complained bitterly about his de facto exclusion from key meetings. ${ }^{148}$ Perhaps most significantly, numerous sources told us that key Secretariat staff colluded with Zimbabwe in preparing public statements that misrepresented official Summit decisions.

Towards the end of the backlash campaign, civil society groups demanded access to the SADC meetings and to records of official decisions. But their complaints fell on deaf ears. This may well have reflected political reality - the unbending will of Mugabe, the de facto withering of the Tribunal due to blocked judicial appointments and the continued acquiescence of other member states. By August 2013 when Mugabe was elected to the SADC's rotating chairmanship, ${ }^{149}$ any astute Secretariat official could see the writing on the wall.

\section{B Civil Society Mobilization to Oppose International Court Backlash}

Civil society participation is a common and distinctive feature of European-style economic communities. The West, East and Southern Africa integration projects are no exception. They include procedures for soliciting the views of civil society actors in collective decision-making processes. All three sub-regions require that civil society groups register with community institutions, a status that enables them to consult with officials and to attend key meetings. To be eligible for registration, civil society groups must demonstrate that their membership extends across each sub-region. Partly to meet this requirement, many bar associations, law societies and human rights NGOs in Africa have organized themselves transnationally.

In all three cases in our study, sub-regional civil society groups were aware of the government's backlash efforts and actively mobilized to oppose them. What, then, explains the groups' varied influence in thwarting the backlash campaigns? Part of the answer is how organized, cohesive and well-resourced the groups were in each sub-region and how close a relationship they developed with community secretariats.

In West Africa, human rights organizations and law societies have been working with the ECOWAS Secretariat for many years. Elsewhere, we explain how human rights appeared on the agenda of ECOWAS in the early 1990s in response to credible evidence of atrocities committed by military forces participating in an ECOWASsanctioned humanitarian intervention in Liberia. ${ }^{150}$ When member states later revamped the sub-region's collective security institutions, they also included broad participation rules for civil society actors. ${ }^{151}$

148 Pillay Speech, supra note 121 , at 4-5.

149 'Mugabe to Become Next SADC Leader', News 24 (20 August 2013), available at www.news24.com/ Africa/Zimbabwe/Mugabe-to-become-next-SADC-leader-20130820 (last visited 17 March 2016).

150 Alter, Helfer, and McAllister, supra note 1, at 744.

151 Decision A/DEC.9/8/94 Establishing Regulations for the Grant to Non-governmental Organisations (NGOs) the Status of Observer within the Institutions of the Community, 6 August 1994, discussed in K. Oteng Kufuor, The Institutional Transformation of the Economic Community of West African States (2006), at 49-50. 
Capitalizing on these rules, human rights groups organized transnationally beginning in 2001, the same year that the ECOWAS Court was created. The West African Bar Association followed in 2004, resolving to 'supplement the work of [ECOWAS] by promoting [the] rule of law, fundamental human rights and democracy in the subregion'. ${ }^{152}$ Human rights groups and the regional bar association partnered with the Secretariat to strengthen the community legal order. The Legal Affairs Directorate actively consulted the groups regarding the 2005 Protocol giving the ECOWAS Court a human rights jurisdiction. And, as described in detail above, the Directorate followed the civil society participation rules, ensuring that advocates were aware of, and could attend, key meetings at which the Gambia's court-curbing proposals were debated.

In East Africa, the EALS and the Pan-African Lawyers Union (PALU) are highly organized and maintain a permanent presence in Arusha, the home of the EAC, the EACJ and other international courts. Founded in 1995 and based in Arusha, the EALS has built personal connections with Secretariat officials and sub-regional judges. The PALU is a more recent creation, founded in 2010 to better coordinate Africa's Anglophone and Francophone bar associations. These organizations operate with a lean, but highly capable, staff. The EALS is also well financed by mandatory dues from attorneys who renew their practice certificates with their national bar association.

Formally, the EALS has observer status with the EAC and the right to participate in Council meetings. ${ }^{153}$ Yet the society's influence has been stymied by a lack of close alignment between its objectives and those of the EAC Office of Legal Counsel. ${ }^{154}$ Attorneys told us that Legal Counsel staff had cancelled meetings at the last minute and lost or delayed their requests for documents. Other EAC practices also minimize participation, either by design or happenstance: 'Council meetings are often planned at the last minute, and there is often little prior notice given to EALS so that it can secure attendance of one of its officers.' ${ }^{155}$

As explained above, EAC officials are focused on carrying out the objectives of member states. Consultations with civil society groups do occur but mainly when their interests overlap with those of the Secretariat. For example, the East African Business Council was regularly consulted regarding drafts of sub-regional economic legislation. ${ }^{156}$ And NGOs working on development, gender, youth, children and business issues are also involved in EAC Secretariat activities. ${ }^{157}$

With regard to human rights groups, however, the EAC's Office of Legal Counsel is more wary. One lawyer told us that the Legal Council staff informally consulted

152 General News Association, West African Bar Association Inaugurated, 24 August 2004, available at www.ghanaweb.com/GhanaHomePage/economy/artikel.php?IBID=64712 (last visited 17 March 2016).

153 Gathii, supra note 31, at 282.

154 EAC Treaty, supra note 30, Art. 69 establishes the EAC Office of Legal Counsel as a body within the EAC Secretariat.

155 Gathii, supra note 31, at 282, n. 214.

156 Interview with a policy coordinator at East African Business Council, Arusha, Tanzania (30 July 2013).

157 Deya, supra note 143. 
with the PALU after governments expressed doubt about a Secretariat report on a legal issue. ${ }^{158}$ The Secretariat also met with the EALS and the PALU to discuss a member state proposal to give the EACJ jurisdiction over international crimes, while, at the same time, sidelining the EALS' key objective of adopting a protocol to confer an express human rights mandate on the court. ${ }^{159}$ Seen in this light, it is not surprising that the Secretariat officials did not consult the EALS and the PALU about Kenya's plans to weaken the EACJ following the N'yongo ruling. The EALS later challenged the lack of civil society participation in the treaty amendment process, and the judges validated their complaint:

We think that construing the Treaty as if it permits sporadic amendments at the whims of officials without any form of consultation with stakeholders would be a recipe for regression to the ... 'lack of strong participation of the private sector and civil society' that led to the collapse of the previous Community. ${ }^{160}$

Yet the court declined to annul the amendments on prudential grounds, declaring that 'the requirement of involvement of people in the Treaty amendment process shall have prospective application'. ${ }^{161}$ This cautious holding may reflect the judges' pragmatic recognition that, although the Secretariat had circumvented rules requiring civil society participation, the amendments were a fait accompli that member states would not reverse.

In Southern Africa, the SADC Lawyers Association was mostly excluded from community-level consultations regarding the Tribunal. Even before Zimbabwe's backlash campaign, the SADC Secretariat and the Association had a standoffish relationship. According to a former member of the Association's leadership, the Secretariat viewed the lawyers group as 'too noisy' and tended to avoid informal contact. In addition, the group's observer status in the SADC has remained in a 'gray area'. The group does not want to formalize its relationship to the community because, according to this official, registered NGOs are pressured to 'toe the line' of the member states and the Secretariat. ${ }^{162}$

The lack of a close relationship with the Secretariat is one reason why the SADC Lawyers Association has moved twice since it was established in 1999 - first, in 2003, from its initial home in Pretoria, South Africa, to Gaborone, Botswana, and again in 2011 from Gaborone back to Pretoria. ${ }^{163}$ The first move was in hopes of working more closely with the Secretariat. The second reflected the difficulty of partnering with SADC officials and the reality that more businesses, law firms and NGOs are based in Pretoria.

Capacity constraints also undermine the influence of the SADC Lawyers Association. Unlike the EALS, which is funded by mandatory dues from individual lawyers, the

158 Interview with Human Rights Advocate L, Arusha, Tanzania (30 July 2013).

159 Interview with Official from the Pan African Lawyer's Association, Arusha, Tanzania (30 July 2013).

160 East Africa Law Society, supra note 55, at 30 (emphasis in original).

161 Ibid., at 44.

162 Interview with a Former Official of the SADC Lawyers Association, Gaborone, Botswana (9 August 2013).

163 Interview with Officials of the Law Society of Botswana, Gaborone, Botswana (8 August 2013). 
Association is dependent on dues collected by national bar associations. National associations often fail to pay or are late in forwarding dues. The lack of stable funding forces the Association to rely on volunteers, making it more difficult to file complaints or amicus briefs with the Tribunal. ${ }^{164}$

Dispersed geography is also a factor. The SADC Lawyers Association and most regional NGOs are based in Pretoria, South Africa, while the SADC Secretariat is based in Gaborone, Botswana. The Tribunal's seat is in Windhoek, Namibia, and procedural rules require that all cases be filed in person. Summit meetings rotate around major cities in the 15 member states. This dispersion makes it more difficult for lawyers and NGOs to develop informal and formal contacts and relationships with SADC judges and officials.

The lack of a strong and cohesive SADC bar association has created space for the civil society stage to be occupied by foreign-funded NGOs such as the Open Society Initiative of Southern Africa (supported by the Soros Foundation) and the Southern Africa Litigation Centre (jointly funded by Soros and the International Bar Association). While these NGOs hire skilled human rights lawyers, they make easy targets for political leaders like Mugabe, who discredit them as thinly veiled fronts for Western nations seeking to interfere with the internal politics of African nations. ${ }^{165}$ The location of these foreign-funded NGOs in the more constitutionally progressive South Africa adds to this perception.

For all of these reasons, the SADC Secretariat mostly sidelined the civil society groups that rallied to save the Tribunal. As noted above, foreign-funded NGOs repeatedly protested their exclusion from meetings at which political leaders debated the Tribunal's fate. The SADC Lawyers Association fared little better. Instead, it focused on public statements and lobbying government officials. ${ }^{166}$ These tactics helped to secure the support of the Ministers of Justice for compromise proposals, but they were insufficient to overcome Zimbabwe's intransigent opposition.

\section{Sub-Regional Parliaments as Potential Venues for Opposition Politics}

Parliamentary bodies associated with regional and sub-regional integration projects may provide another venue for resisting attempts by national executives to circumvent community procedures, including those protecting international courts against political backlashes. Many will find this claim surprising. Conventional wisdom holds that regional legislatures are, with the possible exception of the European Parliament, little

164 Ibid

165 E.g., Permanent Mission of the Republic of Zimbabwe to the United Nations, Statement of Patrick A. Chinamasa (MP), UN Human Rights Council (June 2006), available at www.icnl.org/news/2006/0710_Zimbabwe.pdf (last visited 17 March 2016).

166 See SADC Lawyers Association, Whither the SADC Tribunal: Report of Regional Colloquium on the SADC Tribunal, Johannesburg (March 2013), at 19-20, available at www.sadcla.org/new1/sites/default/files/ Report $\% 20$ of $\% 20$ the\%20Regional\%20Colloquium\%20on\%20the\%20SADC\%20Tribunal_1.pdf (last visited 17 March 2016); SADC Lawyers Association, Statement on SADC Tribunal, Regional Governance Issues, 16 August 2013 (condemning the decision to strip private litigant access to the Tribunal), available at http://www.igd.org.za/index.php/research/international-diplomacy/sadc-institutions/5328-sadclawyers-association-statement-on-sadc-tribunal-regional-governance-issues (last visited 18 March 2016). 
more than talk shops. This is largely true for the ECOWAS Parliament, which lacked any legislative powers or budgetary approval authority until a 2014 institutional overhaul. ${ }^{167}$ The SADC Parliamentary Forum is even weaker. It is not formally recognized as a community institution and does not coordinate its activities with other SADC initiatives. ${ }^{168}$

The situation in East Africa is different. The members of the EALA are elected from their respective national parliaments in proportion to the strength of each member country's political parties. The sub-regional legislature is also financially and politically independent from the member states. As the Nyong'o litigation aptly demonstrates, these attributes make the EALA an attractive venue for opposition politicians. They also provide opportunities for parliamentarians to support international court judges against attacks by national executives.

The EALA was an early supporter of the EACJ in at least three important ways. First, the Assembly passed resolutions urging the EAC Summit to appoint the inaugural group of sub-regional judges and to upgrade the registrar of the Court to an executive position. ${ }^{169}$ Second, three EALA members brought the very first case to the EACJ - a challenge to the authority of the Council of Ministers to supervise the Assembly's legislative agenda. Notably, the EALA as a body supported the suit over the objections of the EAC Legal Secretariat. ${ }^{170}$ The EACJ sided with the Assembly, a decision lauded by civil society groups - whom the court had allowed to file amicus curiae submissions - as a milestone for upholding the rule of law in East Africa. ${ }^{171}$ Third, the EALA has lobbied to increase funding for the EACJ to ensure that the court can continue to hear suits raising human rights issues. ${ }^{172}$ By supporting the activation of the EACJ, bringing its first case and publicly supporting the inclusion of a human rights mandate, the EALA

167 In 2014, the member states expanded the Parliament's powers to include approval of the community budget, certain oversight responsibilities for ECOWAS organs and the appointment of community officials. 'Finally ECOWAS Enhances Power of ECOWAS Parliament', African Examiner (15 December 2014), available at www.africanexaminer.com/finally-ecowas-enhances-the-powers-of-the-ecowas-parliament/ (last visited 17 March 2016).

168 SADC Treaty, supra note 80, Art. 9(1), which establishes SADC institutions, does not mention the Forum. But see SADC Tribunal, Bookie Monica Kethusegile v. SADC Parliamentary Forum, Case No. SADC 02 (2009) (asserting that a SADC Summit decision elevated the Forum to a SADC institution); see also S. Kingah, EU's Engagement with African Sub-Regional Parliaments of ECOWAS, SADC, EAC and AU, UNU-CRIS Working Papers W-2012/8 (2012), at 9, available at www.cris.unu.edu/fileadmin/ workingpapers/W-2012-8.pdf (last visited 17 March 2016).

169 See East African Legislative Assembly, Eight Years of EALA: 2001-2009 (September 2009), at 9 (noting that the EALA passed a resolution urging the Council of Ministers to appoint EACJ judges and a registrar to establish their terms of service).

${ }^{170}$ On the objections of the EAC Legal Counsel, see EALA Legislative Assembly, Official Report of the Proceedings of EALA, 59th Sitting - First Assembly: First Meeting-Fifth Session, 6 December 2005, available at www. eala.org/key-documents/doc_details/70-6-december-2005.html (last visited 17 March 2016).

171 EACJ, Mwatela v. EAC, Application No. 1 of 2005, Ruling, 1 October 2006 (Tanzania), at 15.

172 S. Bageine, Budget Speech of the EAC for Financial Year 2013/2014 to the EALA, 30 May 2013; see also Roundtable on Strengthening the Implementation of Human Rights in the EAC Region: The Role of the East African Legislative Assembly, Arusha, Tanzania (27 May 2011) (urging the East Africa Legislative Assembly to advocate for increased resources to enable the EACJ to effectively carry out its human rights protection mandate), available at www.wfd.org/upload/docs/Communique\%20-\%20Launch\%20of\%20 Human\%20Rights\%20Handbook\%20in\%20EALA.pdf (last visited 17 March 2016). 
provided an additional venue to defend the sub-regional judges against the wrath of national executives.

\section{Conclusion}

This article has described three credible attempts to sanction sub-regional international courts in Africa for rulings that criticized the behaviour of national governments. In ECOWAS, the Secretariat followed procedures that enabled civil society groups to oppose the Gambia's court-curbing campaign, preventing officials from colluding behind closed doors to hobble the fledgling sub-regional court. Even though Gambian President Jammeh's proposals were the most modest of the three backlash attempts we analyse, they failed to secure the support of other ECOWAS member states.

In East Africa, Kenyan government officials called rushed, unofficial meetings to circumvent EAC decision-making processes. The speed of Kenya's response, and the small number of EAC member states, made it difficult for civil society groups to thwart these extra-legal efforts. Still, Kenya's Attorney General failed to accomplish the government's more radical goals: the EACJ was not disbanded; its Kenyan judges were not removed from office and the government ultimately complied with the offending EACJ ruling.

In the SADC, national political leaders eventually acquiesced to Zimbabwean President Mugabe's demands, allowing his blocking of judicial reappointments to de facto suspend the Tribunal and later agreeing to strip the right of private access. But this successful backlash was hard fought. The SADC Secretariat and sympathetic government officials initially countered Mugabe's legal arguments, pushed for compromises and repeatedly returned the issue to the Ministers of Justice and Attorneys General for further study rather than agree to Mugabe's demands. Indeed, Zimbabwe's efforts to discredit the legal validity of the Tribunal and its rulings in the Campbell cases failed. In the end, however, Mugabe's persistence, tenacity and wily political tactics won out.

We have argued that successful governments sanctioning efforts depend on two factors - the decision by community secretariats to follow or circumvent procedures that require consultations with non-state actors and the mobilization strategies of human rights groups and lawyers associations in support of the courts. In ECOWAS, Secretariat officials adhered to procedural rules for notifying civil society groups and facilitating their participation in key meetings. Public and private lobbying by these groups helped to reframe the Gambia's court-curbing initiative as a self-interested reaction to rulings that exposed the country's abysmal human rights record. In the EAC, Kenya rapidly convened unofficial meetings to circumvent more deliberative consultation procedures, creating a fait accompli of court reforms that, while less severe than what the government initially wanted, have nonetheless affected the EACJ's subsequent trajectory. In the SADC, Zimbabwean officials relied on public spin, misinformation, closed-door Summit meetings and a relentless campaign by the lionized 
nationalist leader, Robert Mugabe, who blocked Tribunal reappointments and wore down moderate governments opposed to the backlash.

In closing, we address three broader theoretical questions that arose as we conducted our research and in presenting our findings: (i) why did sub-regional judges rule against states instead of avoiding decisions that were likely to provoke negative reactions; (ii) why were sub-regional Secretariats easier for governments to control than sub-regional courts and (iii) were differences in judicial appointment rules part of a rational plan to limit the courts' powers?

Why did judges not anticipate, and thus avoid, provoking the backlashes? The time between interim and final rulings provided sub-regional judges with information about member state preferences and an opportunity to back down from looming confrontations with governments. When we asked the judges why they remained unyielding in the face of strident government opposition, they cited their obligation to follow the law. This is hardly a surprising justification, but it is also a rational and strategic response. If judges are seen as caving in to political demands and ignoring the law, their authority and raison d'etre may be called into question. On the other hand, expansive rulings create easy targets for political rebuke. This may explain the post-backlash caution exhibited by the ECOWAS Court and the EACJ in fashioning remedial awards to prevailing private litigants.

Yet this does not explain the SADC Tribunal's confrontational approach to Zimbabwe, both in the initial Campbell rulings and in subsequent contempt orders. The SADC Tribunal's former president, Ariranga Pillay, is fiercely independent, and, to this day, he strongly defends the rightness of the Tribunal's decisions. The judges were also arguably channelling sympathy for the rule-of-law advocates in Zimbabwe as well as frustration with SADC political institutions, which were unwilling to call Zimbabwe to task for numerous violations of the law.

Why do sub-regional judges act with greater independence in comparison to sub-regional Secretariats? The judges on the courts we examined, although clearly aware of the limits of their authority, displayed greater willingness to act independently than did Secretariat officials. Lawyers may find this unsurprising, but the reasons for this difference are worth underscoring, since political scientists and politicians often expect all supranational actors to be easily influenced agents of states. First, Secretariats exist to facilitate member state cooperation and to promote Community objectives, tasks that require close collaboration with governments. Second, Secretariats are not expected to follow legal procedures in the scrupulous way that judges do when adjudicating cases. Third, Secretariat officials tend to be diplomats or individuals with national government experience or aspirations, while judges on Africa's sub-regional courts come from, and often return to, high-level national judicial appointments. For example, the SADC Tribunal President Pillay was Mauritius' chief justice from 1996 to 2007, which may explain his unwillingness to brook Mugabe's intimidation tactics.

Was the ECOWAS Court designed to be more independent, and the EACJ and the SADC Tribunal designed to be more vulnerable? The ECOWAS Court has a different structure than its sub-regional counterparts. It has an express human rights jurisdiction, and the member states as a group have repeatedly supported and even bolstered the 
court's authority. The creation of the Judicial Council, the professional independence of the Secretariat, and the rejection of the Gambia's backlash effort all reflect a deeper governmental commitment to the ECOWAS Court as an adjudicator of human rights complaints.

This does not imply, however, that the analogous structures of the courts in the SADC and the EAC reflect the rational design choices of sovereignty-jealous states. Governments in East Africa have refrained from conferring human rights jurisdiction on the EACJ and regularly contest the Court's backdoor adjudication of human rights suits. And the EACJ Appellate Division - itself a result of the backlash - provides a mechanism to reverse more expansive First Instance rulings. Yet both chambers of the EACJ remain stubbornly independent. ${ }^{173}$ The SADC Tribunal's fate also cannot be explained by rational design. The appointment procedure that Zimbabwe exploited to suspend the Tribunal appears to be more of an oversight than an intentional tool for court curbing. And the Tribunal's key rulings, which involved the politically incendiary issue of minority white landowners, risked generating a backlash that even a court with more judge-friendly appointment rules may not have survived.

That international court rulings often elicit negative reactions from defending states is old news. Yet most of these responses are the stuff of ordinary politics. A government that publicly criticizes judicial rulings, drags its feet in implementing a judgment or only partly remedies legal violation is not engaging in a concerted backlash campaign to destroy the court or radically curb its powers. Nor do such actions prove that international court rulings, in the aggregate and over time, are unhelpful to those who seek to pressure governments to revise challenged laws and policies.

At some point, however, a state's negative reaction crosses the line between ordinary and extraordinary politics, creating an existential threat that requires civil society groups, lawyers, international officials and others to mobilize to save the tribunal. If and when such threats arise elsewhere in the world, the credible backlashes against three similarly situated sub-regional courts in Africa - and their divergent outcomes - will provide important guideposts. The key finding of our research is that transparency and adherence to process limit the political space for aggrieved states to react and enable tribunal supporters to mobilize against court-curbing proposals.

173 Gathii, 'Saving the Serengeti: Africa's New International Judicial Environmentalism', 16 Chicago Journal of International Law (2016) 386. 